\title{
Measuring social origin, cognitive ability and educational attainment in the 1970 British Cohort Study (BCS70)
}

Bastian A. Betthäuser ${ }^{1,2}$, Mollie Bourne ${ }^{3}$, Erzsébet Bukodi ${ }^{1,2}$

\footnotetext{
${ }^{1}$ Nuffield College, Oxford

2 Department of Social Policy and Intervention, University of Oxford

${ }^{3}$ EngineeringUK, London
} 


\section{Contents}

1 Introduction 6

2 The British Cohort Study 1970

3 Parental Social Class 8

4 Parental Status 11

5 Parental Education $\quad 13$

6 Parental Income 16

7 Cognitive Ability 17

8 Respondent Educational Attainment 18

9 Associations between Social Origin Measures 25

10 Social Origin and Cognitive Ability 30

11 Social Origin and Educational Attainment 33

12 Cognitive Ability and Educational Attainment 37

Appendix 39

Acknowledgements: The authors are grateful to the Centre for Longitudinal Studies (CLS), UCL Institute of Education, for the use of the data used and to the UK Data Service for making them available. The research for this Data Note was supported by the Nuffield Foundation (EDU/42195) and the Economic and Social Research Council (ESRC Grant ES/J500112/1). Neither CLS, the UK Data Service the Nuffield Foundation or the ESRC bear any responsibility for the work presented in this Data Note.

The Nuffield Foundation is an independent charitable trust with a mission to advance social well-being. It funds research that informs social policy, primarily in Education, Welfare, and Justice. It also funds student programmes that provide opportunities for young people to develop skills in quantitative and qualitative methods. The Nuffield Foundation is the founder and co-funder of the Nuffield Council on Bioethics and the Ada Lovelace Institute. The Foundation has funded this project, but the views expressed are those of the authors and not necessarily the Foundation. Visit www.nuffieldfoundation.org.

The Economic and Social Research Council ESRC is part of UK Research and Innovation (UKRI), a new organisation that brings together the UK's seven research councils, Innovate UK and Research England to maximise the contribution of each council and create the best environment for research and innovation to flourish. The vision is to ensure the UK maintains its world-leading position in research and innovation.

Data Availability Statement. The data that support the work presented in this Data Note are available from the UK Data Archive. Restrictions apply to the availability of these data, which were used under license for this study. Data are available at http://doi.org/10.5255/UKDA-SN-5641-2 with the permission of the UK Data Archive. 


\section{List of Tables}

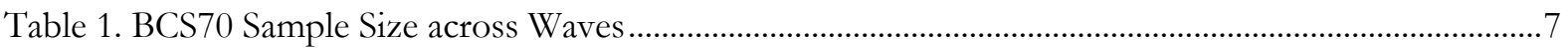

Table 2. Missingness on Key Variables ..........................................................................................................

Table 3. Distribution of Mothers' and Fathers' Social Class based on SOC90 derived from OUG80

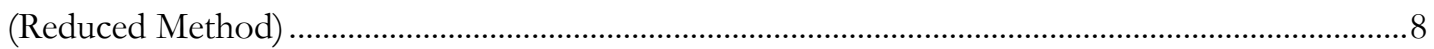

Table 4. Distribution of Parental Social Class based on SOC90 derived from OUG80 …..............................9

Table 5. Distribution of Fathers' and Mothers' Social Class based on SOC2000 provided by Paul Gregg (Reduced Method).

Table 6. Distribution of Parental Social Class based on SOC2000 provided by Paul Gregg - Parents (dominance approach) 10

Table 7. Distribution of Different Measures of Parental Social Class (\%) ................................................... 10

Table 8. Distribution of Mothers', Fathers' and Parental CG Social Status Scores (Quartiles) .................... 11

Table 9. Distribution of Mothers', Fathers' and Parental CAMSIS Social Status Scores (Quartiles) .......... 12

Table 10. Pearson's Correlations: Mothers', Fathers' and Parental Status Scores (CG and CAMSIS) ....... 13

Table 11. Fathers' and mothers' Highest Educational Qualifications................................................................. 14

Table 12. Parental Education: Composite measure, BSC70 ......................................................................... 15

Table 13. Parental Education: Scores of relative scale (\% falling below given educational level), BCS70 15

Table 14. BCS70 Constructed Income Variable ............................................................................................... 16

Table 15. BCS70 Constructed Income Variable Deciles .................................................................................... 16

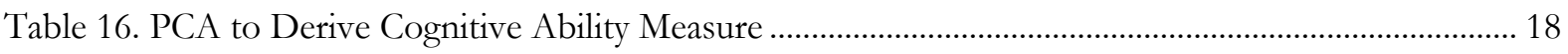

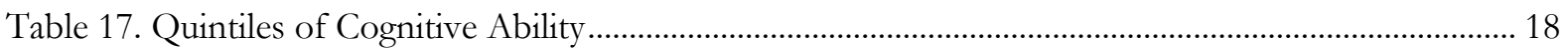

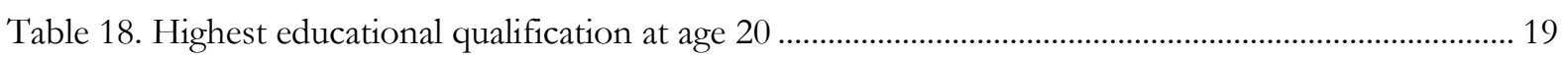

Table 19. Highest educational qualification at age 38 .............................................................................. 19

Table 20. Passing of Threshold at Key Stage 5 by age 20 (academic only) ……………………………......... 19

Table 21. Passing of Threshold at Key Stage 5 by age 38 (academic only) ................................................... 19

Table 22. Passing of Threshold at Key Stage 5 by age 20 (academic \& vocational) ...................................... 20

Table 23. Passing of Threshold at Key Stage 5 by age 38 (academic \& vocational) ...................................... 20

Table 24. Crosstab of highest educational qualification at age 20 and passing of KS5 Threshold (academic

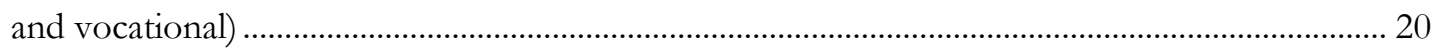

Table 25. Transition to Higher Education by age 38 (academic only), excluding sub-degree ...................... 21

Table 26. Transition to Higher Education by age 38 (academic only), including sub-degree....................... 21

Table 27. Transition to Higher Education by age 38 (academic \& vocational), excluding sub-degree....... 21

Table 28. Transition to Higher Education by age 38 (academic \& vocational), including sub-degree........ 21

Table 29. Crosstab of highest educational qualification at age 38 and transition to HE (academic \& vocational), excluding sub-degree

Table 30. Performance lower sec. level - Number of GCSE/GNVQ Qualifications at Grades A*_C..... 23

Table 31. Performance upper sec. level - Number of A-levels Passed............................................................. 23

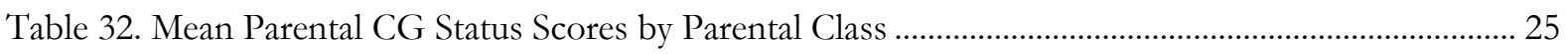

Table 33. One-way ANOVA: Parental Status by Parental Class ..................................................................... 25

Table 34. Mean Parental Education (7-level Relative Scale, Normalised) by Parental Class ........................ 26

Table 35. One-way ANOVA: Parental Education by Parental Class ............................................................ 26

Table 36. Cross-tabulation of CG Parental Status Quartiles and Parental Education (Composite measure) 
Table 37. Parental Income by Parental Class, CG Status Quartiles and Education (Composite measure) 28

Table 38. One-way ANOVA: Parental Income by Parental Class

Table 39. Spearman Rank Correlations: Parental Class, CG Status Quartiles, Education (Composite Measure) and Income Quartiles

Table 40. Pearson Correlations: Parental Class, CG Status (Original Scale), Education (Composite Measure and Relative Scale) and Income (Original Scale) ............................................................................. 29

Table 41. Mean Cognitive Ability by Parental Class...................................................................................... 30

Table 42. Mean Cognitive Ability by Parental CG Status Quintiles ............................................................... 30

Table 43. Cross-Tabulation of Parental CG Status Quintiles by Cognitive Ability Quintiles ..................... 31

Table 44. Mean Cognitive Ability by Parental Education............................................................................... 31

Table 45. Mean Cognitive Ability by Parental Income Quintiles .................................................................. 32

Table 46. Average Centre Four Global Log Odds Ratios and a Test of Significance in the Differences .. 32

Table 47. Cross-Tabulation of Parental Class by Cohort Members' Educational Attainment at age 38 .... 33

Table 48. Cross-Tabulation of Parental Education (Combined Approach 2) by Cohort Members'

Educational Attainment at age 38.

Table 49. Cross-Tab. of Parental CG Status Quartiles by Cohort Members' Educ. Attainment at age 3835

Table 50. Cross-Tab. of Parental Income Quartiles by Cohort Members' Educ. Attainment at Age 38 ... 36

Table 51. Mean Cognitive Ability by Educational Attainment at Ages 20 and 38 ....................................... 37

Table 52. Mean Cognitive Ability by Educational Attainment Thresholds at Ages 20 and 38 .................. 38

Table 53. Mean Cognitive Ability Scores by Type of Educational Threshold (Age 38) ............................... 38

Table 54. Details on coding of variables on fathers' and mothers' educational attainment.......................... 39

Table 55. Cross-tabulation between Parental Social Class and Parental Education (Composite measure) 39 


\section{List of Figures}

Figure 1. Boxplot Distribution of Mothers' and Fathers' CG Status Scores (normalised using theoretical $\max / \mathrm{min})$

Figure 2. Boxplot distribution of Mothers' and Fathers' CAMSIS Status Scores (normalized using observed $\max / \mathrm{min})$ 12

Figure 3. Distribution of Parental Education (Dominance Approach) .......................................................... 14

Figure 4. Frequency Distribution (Raw Values) and Percentile Distribution (Log-transformed Values) ... 17

Figure 5. Distribution of Cognitive Ability ............................................................................................... 18

Figure 6. Performance at lower sec. level — Number of GCSE/GNVQ qualifications at grades A* - C 24

Figure 7. Performance at upper secondary level - Number of A levels passed ........................................... 24

Figure 8. Boxplot Distribution of Parental CG Status Scores by Parental Class ......................................... 25

Figure 9. Proportion of Cases: (i) Neither Parent has Any Qualifications, and (ii) At least one parent has a

Degree-Level Qualifications, by Parental Class ............................................................................... 27

Figure 10. Boxplot Distribution of Parental CG Status Scores (Original Scale) by Parental Education

(Composite measure) ................................................................................................................. 27

Figure 11. Boxplot Distribution of Cognitive Ability by Parental Class ....................................................... 30

Figure 12. Boxplot Distribution of Cognitive Ability by Parental CG Status Quintiles................................. 31 


\section{Introduction}

This data note was prepared for the research project on Social Origins, Cognitive Ability and Educational Attainment: A Birth Cohort and Life-Course Perspective. The document will present descriptive statistics for the key variables in the British Cohort Study (BCS70) data that of relevance the project. ${ }^{4}$ The main independent variables are measures of respondents' cognitive ability in childhood and the parental education, class, status and income. The key dependent variables are measures of respondents' highest qualification completed and measures indicating whether respondents have crossed certain educational qualification thresholds, especially whether they have completed A-levels and whether they have completed a higher education qualification. Furthermore, the research project aims to use measures of respondents' performance at Key Stage 4 (GCSEs) and Key Stage 5 to identify the relative importance of primary and secondary effects of parental background on respondent's educational attainment.

Section 2 will provide a brief introduction to the BCS70 dataset, including information on the size of the sample for analysis; a description is provided of the amount of missing data on each variable and the resulting final number of valid cases. Sections $3-6$ will examine each of the dimensions of social origin in turn and describe their distributions. Section 7 will describe the distribution of respondents' cognitive ability in the sample, while Section 8 focuses on respondents' educational attainment. Sections 9 through 12 will use cross-tabulations and correlations to present the associations between the above measures.

\section{The British Cohort Study 1970}

The 1970 British Cohort Study (BCS70) is a longitudinal study which began collecting data on 17,198 babies born in England, Scotland, Wales and Northern Ireland in a particular week in April 1970 (specifically, from 00.01 hours on Sunday, 5th April to 24.00 hours on Saturday, 11th April 1970). It was estimated that not more than five percent and not less than two percent of the births during this week in in England, Scotland, Wales and Northern Ireland have been missed and are therefore not present in the survey.

After the initial birth survey, Northern Irish participants were dropped from the sample. The surveys at ages 5 and 10 augmented their samples by adding immigrants born in the same week. Consequently, the sample only includes immigrants who moved to Britain before the age of 16, as there were no attempts to include further members beyond the age 16 survey in 1986. Since the birth survey in 1970, there have been eight 'sweeps' of all cohort members at ages 5, 10, 16, 26, 30, 34, 38 and 42. The most recent sweep of the BCS70 was conducted in 2012-2013. CLS will carry out new surveys of the BCS70 cohort at age 46 in 2016, and age 50 in 2020. With each successive sweep of data collection, the scope of enquiry has broadened from a strictly medical focus at birth, to encompass physical and educational development at the age of five, physical, educational and social development.

At each sweep, different sources and methods were used to gather information on the cohort members. In the birth survey, the midwife present at the birth completed a questionnaire and supplementary information was obtained from clinical records. As the cohort members got older, the tools and information gathered changed. Health Visitors interviewed the parents, teachers completed questionnaires, medical examinations

\footnotetext{
${ }^{4}$ University of London, Institute of Education, Centre for Longitudinal Studies. (2016). 1970 British cohort study response dataset, 1970-2012 (3rd ed.). UK Data Service. SN: 5641, http://doi.org/10.5255/UKDA-SN-5641-2
} 
were carried out, and cohort members themselves participated in educational assessments. In certain sweeps, cohort members have also kept nutrition and activity diaries.

Table 1 shows the development of the number of participants across the different waves of data collection. Note that a large share of the reduction in the sample size between Wave 1 and Wave 2 may be due to the exclusion of individuals born in Northern Ireland after the first sweep of data collection (see introduction). The descriptive statistics presented in this data note were calculated without applying weights. The documentation for Wave 3 from which information on parental characteristics was taken concludes that the achieved sample in 1980 does not differ greatly from the birth sample in 1970 with respect to several key characteristics (pp. 125-27).

Table 1. BCS70 Sample Size across Waves

\begin{tabular}{cccc}
\hline Wave & Year & Age & $N$ \\
\hline \hline Wave 1 & 1970 & 0 & 17,196 \\
Wave 2 & 1975 & 5 & 13,135 \\
Wave 3 & 1980 & 10 & 14,875 \\
Wave 4 & 1986 & 16 & 11,622 \\
Wave 5 & 1996 & 26 & 9,003 \\
Wave 6 & $1999-2000$ & 30 & 11,261 \\
Wave 7 & $2004-2005$ & 34 & 9,665 \\
Wave 8 & $2008-2009$ & 38 & 8,874 \\
Wave 9 & $2012-2013$ & 42 & 9,841 \\
Wave 10 & 2016 & 46 & N/A \\
Wave 11 & 2020 & 50 & N/A \\
\hline
\end{tabular}

Table 2. Missingness on Key Variables

\begin{tabular}{|c|c|c|c|c|c|c|}
\hline & \multicolumn{2}{|c|}{ Per V ariable: Missing } & \multicolumn{2}{|c|}{ Cumulative: Missing } & \multicolumn{2}{|c|}{ Cumulative: Remaining } \\
\hline & $\mathbf{N}$ & $\%$ & $\mathbf{N}$ & $\%$ & $\mathbf{N}$ & $\%$ \\
\hline $\begin{array}{l}\text { Overall BCS70 sample at } \\
\text { Wave } 3 \text { (Age 10) }\end{array}$ & $\longrightarrow$ & $100.00 \%$ & - & $100.00 \%$ & 14875 & $100.00 \%$ \\
\hline Cognitive Ability & 3480 & $23.39 \%$ & 3480 & $23.39 \%$ & 11395 & $76.61 \%$ \\
\hline $\begin{array}{l}\text { Highest qualification (At } \\
\text { age 34) }\end{array}$ & 3681 & $24.75 \%$ & 0 & $23.39 \%$ & 11395 & $76.61 \%$ \\
\hline $\begin{array}{l}\text { Parental class (Reduced } \\
\text { method) }\end{array}$ & 1730 & $11.63 \%$ & 848 & $29.10 \%$ & 10547 & $70.90 \%$ \\
\hline $\begin{array}{l}\text { Parental status } \\
\text { (Chan/Goldthorpe) }\end{array}$ & 1730 & $11.63 \%$ & 0 & $29.10 \%$ & 10547 & $70.90 \%$ \\
\hline $\begin{array}{l}\text { Parental education } \\
\text { (Composite Measure) }\end{array}$ & 1414 & $9.51 \%$ & 0 & $29.10 \%$ & 10547 & $70.90 \%$ \\
\hline
\end{tabular}

Notes:6581 further cases are missing information on parental income, reducing the final sample size to 3966 for analyses involving this measure. 


\section{$3 \quad$ Parental Social Class}

Two sets of measures of parental class were generated using the BCS70 Data. The construction of the first set of parental social-class variables first involved allocating SOC90 codes to mothers and fathers based on the OPCS Classification of Occupations 1980 (CO80) codes given in the original data. The CO80 occupational group codes were taken from Wave 3 (1980), i.e. when children were 10 years old. Based on the information on parents' SOC90 and on parents' employment status, NS-SEC conversion tables (full method, reduced method and simplified method) were used to allocate fathers and mothers to a social class position within NS-SEC. ${ }^{5}$ A set of variables was generated indicating the social class position of fathers and mothers in terms of the full method, the reduced method and the simplified method. Table 3 displays the distribution of social class for mothers and fathers using the reduced method.

Table 3. Distribution of Mothers' and Fathers' Social Class based on SOC90 derived from OUG80 (Reduced Method)

\begin{tabular}{lcccc}
\hline & \multicolumn{2}{c}{ Mothers } & \multicolumn{2}{c}{ Fathers } \\
\cline { 2 - 5 } & $\mathbf{\%}$ & $\mathbf{N}$ & $\mathbf{\%}$ & $\mathbf{N}$ \\
\hline \hline 1. Higher managerial & 1.1 & 81 & 12.02 & 1,113 \\
2. Lower managerial & 16 & 1,178 & 18.68 & 1,730 \\
3. Intermediate & 21.47 & 1,581 & 5.78 & 535 \\
4. Small employers & 6.57 & 484 & 14.33 & 1,327 \\
5. Lower supervisory & 5.2 & 383 & 19.7 & 1,824 \\
6. Semi routine & 22 & 1,610 & 11.25 & 1,042 \\
7. Routine & 28 & 2,046 & 18.24 & 1,689 \\
\hline Missing & - & 4,774 & - & 2,877 \\
Total & 100 & 12,137 & 100 & 12,137 \\
\hline
\end{tabular}

The dominance method was then used to construct the parental social-class measure. Following the approach adopted by Bukodi and Goldthorpe (2013: 14), 'husband's class is taken to dominate wife's class unless the latter is higher in the ordering of the classes as 1, 2, 3-5, 6, 7, in which case wife's class dominates'. Importantly no adjustment could be made based on fathers or mothers being in part-time or full-time work due to lacking information on this dimension of parents' work. Table 4 shows the distribution of the parental social-class variable. For comparative purposes it gives the distribution of the parental class variables using the simplified, reduced and full method.

\footnotetext{
${ }^{5}$ For further information on the simplified, reduced and full method of allocating individuals to NS-SEC classes based on their occupational information see Office for National Statistics (2005) The National Statistics Socio-Economic Classification: User Manual. Palgrave: Newport (available online).
} 
Table 4. Distribution of Parental Social Class based on SOC90 derived from OUG80

\begin{tabular}{lcccccc}
\hline & \multicolumn{2}{c}{ Simplified Method } & \multicolumn{2}{c}{ Reduced Method } & \multicolumn{2}{c}{ Full Method } \\
\cline { 2 - 7 } & $\mathbf{\%}$ & $\mathbf{N}$ & $\mathbf{\%}$ & $\mathbf{N}$ & $\mathbf{\%}$ & $\mathbf{N}$ \\
\hline \hline 1. Higher managerial & 11.22 & 1,133 & 11.45 & 1,156 & 9.95 & 1,005 \\
2. Lower managerial & 21.08 & 2,129 & 22.69 & 2,292 & 24.8 & 2,505 \\
3. Intermediate & 12.52 & 1,265 & 8.87 & 896 & 8.84 & 893 \\
4. Small employers & 11.65 & 1,177 & 12.97 & 1,310 & 12.46 & 1,258 \\
5. Lower supervisory & 15.39 & 1,554 & 18.26 & 1,844 & 18.24 & 1,842 \\
6. Semi routine & 15.02 & 1,517 & 12.76 & 1,289 & 12.71 & 1,284 \\
7. Routine & 13.12 & 1,325 & 13 & 1,313 & 13 & 1,313 \\
\hline Missing & - & 2,037 & - & 2,037 & - & 2,037 \\
Total & 100 & 12,137 & 100 & 12,137 & 100 & 12,137 \\
\hline
\end{tabular}

A second set of measures for parental class was then generated using SOC2000 codes of fathers' and mothers' occupation supplied by Tim Morris as part of the ESRC Project 'An examination of the impact of family socio-economic status on outcomes in late childhood and adolescence' (ESRC Grant: RES-06023-0011) led by Paul Gregg. As part of this project the questionnaire response text strings in the BCS70 and NCDS data were processed using the CASCOT (Computer Assisted Structured Coding Tool) programme to assign Standard Occupational Classification 2000 codes (SOC2000) and Standard Occupational Classification 90 (SOC90) codes to entries. Please see the Data Note prepared by Tim Morris on this procedure for further details. ${ }^{6}$ Using the SOC2000 codes supplied by Paul Gregg and using detailed information on mothers' and fathers' employment status, the simplified, reduced and full method were used to generate measures of parental class. Table 5 shows the distribution of the reduced measure for mothers and fathers.

Table 5. Distribution of Fathers' and Mothers' Social Class based on SOC2000 provided by Paul Gregg (Reduced Method)

\begin{tabular}{lcccc}
\hline & \multicolumn{2}{c}{ Mothers } & \multicolumn{2}{c}{ Fathers } \\
\cline { 2 - 5 } & $\mathbf{\%}$ & $\mathbf{N}$ & $\mathbf{\%}$ & $\mathbf{N}$ \\
\hline \hline 1. Higher managerial & 1.57 & 116 & 11.31 & 1,057 \\
2. Lower managerial & 13.76 & 1,017 & 17.63 & 1,648 \\
3. Intermediate & 21.22 & 1,568 & 6.06 & 566 \\
4. Small employers & 6.29 & 465 & 14.36 & 1,342 \\
5. Lower supervisory & 4.3 & 318 & 20.1 & 1,879 \\
6. Semi routine & 25.27 & 1,867 & 11.82 & 1,105 \\
7. Routine & 27.58 & 2,038 & 18.71 & 1,749 \\
Missing & - & 4,748 & - & 2,791 \\
Total & 100 & 12,137 & 100 & 12,137 \\
\hline
\end{tabular}

The dominance method was then used to construct the parental social-class measure. In addition to the simplified, reduced and full method of allocating individuals to NSSEC an alternative approach was used. First, all individuals were allocated to NS-SEC classes as if they were employees, using their SOC2000 codes. In a second step, a dummy variable indicating self-employment was used to reallocate individuals who are coded as self-employed. In a third step, individuals for whom no information is available on whether they

${ }^{6}$ http://doc.ukdataservice.ac.uk/doc/7023/mrdoc/pdf/ncds_bcs_occupation_coding.pdf 
are self-employed or not were reallocated using the simplified method of allocating individuals to NS-SEC classes. The distribution of this third measure of parental class is shown in Table 6, which also shows the measure of parental NSSEC that was included in the data set provided by Paul Gregg,

Table 6. Distribution of Parental Social Class based on SOC2000 provided by Paul Gregg - Parents (dominance approach)

\begin{tabular}{lcccccccccc}
\hline & \multicolumn{2}{c}{$\begin{array}{c}\text { Paul Gregg } \\
\text { Variable }\end{array}$} & \multicolumn{2}{c}{$\begin{array}{c}\text { Simplified } \\
\text { Method }\end{array}$} & \multicolumn{2}{c}{$\begin{array}{c}\text { Reduced } \\
\text { Method }\end{array}$} & \multicolumn{2}{c}{ Full Method } & \multicolumn{2}{c}{$\begin{array}{c}\text { Alternative } \\
\text { Method }\end{array}$} \\
\cline { 2 - 12 } & $\mathbf{\%}$ & $\mathbf{N}$ & $\mathbf{\%}$ & $\mathbf{N}$ & $\mathbf{\%}$ & $\mathbf{N}$ & $\mathbf{\%}$ & $\mathbf{N}$ & $\mathbf{\%}$ & $\mathbf{N}$ \\
\hline \hline $\begin{array}{l}\text { 1. Higher } \\
\text { managerial }\end{array}$ & 11.47 & 1,158 & 11.47 & 1,158 & 11.18 & 1,129 & 10.16 & 1,026 & 11.41 & 1,152 \\
$\begin{array}{l}\text { 2. Lower } \\
\text { managerial }\end{array}$ & 18.54 & 1,873 & 18.54 & 1,873 & 21.24 & 2,145 & 22.81 & 2,304 & 20.06 & 2,026 \\
$\begin{array}{l}\text { 3. } \\
\text { Intermediate }\end{array}$ & 12.72 & 1,285 & 12.72 & 1,285 & 9.24 & 933 & 9.22 & 931 & 13.17 & 1,330 \\
$\begin{array}{l}\text { 4. Small } \\
\text { employers }\end{array}$ & 12.27 & 1,239 & 12.27 & 1,239 & 12.96 & 1,309 & 12.44 & 1,256 & 8.88 & 897 \\
$\begin{array}{l}\text { 5. Lower } \\
\text { supervisory }\end{array}$ & 15.33 & 1,548 & 15.33 & 1,548 & 18.61 & 1,880 & 18.6 & 1,879 & 13.08 & 1,321 \\
$\begin{array}{l}\text { 6. Semi } \\
\text { routine }\end{array}$ & 16.22 & 1,638 & 16.22 & 1,638 & 13.69 & 1,383 & 13.69 & 1,383 & 17.7 & 1,788 \\
$\begin{array}{l}\text { 7. Routine } \\
\text { Missing }\end{array}$ & 13.46 & 1,359 & 13.46 & 1,359 & 13.08 & 1,321 & 13.08 & 1,321 & 15.7 & 1,586 \\
\hline \begin{tabular}{l} 
Total \\
\hline
\end{tabular} & - & 2,037 & - & 2,037 & - & 2,037 & - & 2,037 & - & 2,037 \\
\hline
\end{tabular}

For comparative purposes, Table 7 shows the distribution of a selection of the measures of parental class described above in direct comparison to the distribution of parental class shown in Bukodi and Goldthorpe (2013).

Table 7. Distribution of Different Measures of Parental Social Class (\%)

\begin{tabular}{lcccc}
\hline & $\begin{array}{c}\text { Based on } \\
\text { SOC90/ } \\
\text { reduced } \\
\text { method }\end{array}$ & $\begin{array}{c}\text { Based on } \\
\text { SOC200/ } \\
\text { reduced } \\
\text { method }\end{array}$ & $\begin{array}{c}\text { Based on } \\
\text { SOC2000/ } \\
\text { alternative } \\
\text { method }\end{array}$ & $\begin{array}{c}\text { Bukodi \& } \\
\text { Goldthorpe } \\
\text { (2013) }\end{array}$ \\
\hline \hline 1. Higher managerial & 11.45 & 11.18 & 11.41 & 11.9 \\
2. Lower managerial & 22.69 & 21.24 & 20.06 & 20.7 \\
\hline 3. Intermediate & 8.87 & 9.24 & 13.17 & 8.7 \\
4. Small employers & 12.97 & 12.96 & 8.88 & 12.6 \\
5. Lower supervisory & 18.26 & 18.61 & 13.08 & 18.4 \\
6. Semi routine & 12.76 & 13.69 & 17.7 & 11.2 \\
\hline 7. Routine & 13 & 13.08 & 15.7 & 16.5 \\
\hline Total & 100 & 100 & 100 & 100 \\
\hline
\end{tabular}




\section{$4 \quad$ Parental Status}

As is the case for the construction of the parental social class variables, for the construction of the parental status variables information from Wave 3 (1980) is used, i.e. when children were 10 years old. Two measures of parental status have been constructed. The first is based on the Chan-Goldthorpe (CG) status order (Chan and Goldthorpe, 2004). Mothers' and fathers' Chan-Goldthorpe (CG) status scores were derived from their respective SOC90 codes. The measure has been normalized to a 0 to 1 scale using the minimum and maximum of -0.6 and +0.6 . Figure 1 illustrates the distribution of mothers' and fathers' CG status scores.

Figure 1. Boxplot Distribution of Mothers' and Fathers' CG Status Scores (normalised using theoretical $\max / \min )$

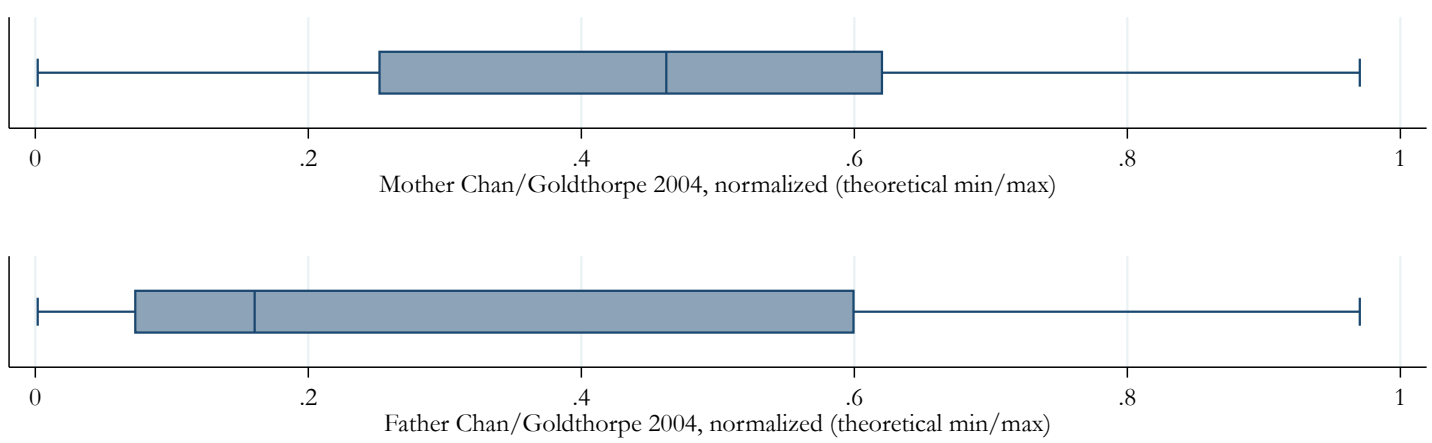

Mothers' mean CG status score is 0.45 (Std. Dev. $=0.25$ ) compared with fathers' mean score of 0.33 (Std. Dev. $=0.31$ ). Surprisingly, mothers tend to occupy a higher social position than fathers. This is also the case in the LSYPE data (see LSYPE Data Note). Table 8 presents the frequencies of mothers' and fathers' CG social status scores grouped into quartiles.

A parental social status variable was then constructed by taking the highest status score between the mother and the father. In instances where one was missing, the non-missing score was assigned using the modal value in the overall distribution. The quartiles for this variable are given in Table 8 . The mean score for parental status is 0.46 with standard deviation 0.29 .

Table 8. Distribution of Mothers', Fathers' and Parental CG Social Status Scores (Quartiles)

\begin{tabular}{lcccccc}
\hline & & $\begin{array}{c}\text { Mothers' Social } \\
\text { Status }\end{array}$ & \multicolumn{2}{c}{ Fathers' Social Status } & \multicolumn{2}{c}{ Parental Social Status } \\
\cline { 3 - 7 } & $\mathbf{\%}$ & $\mathbf{N}$ & $\mathbf{\%}$ & $\mathbf{N}$ & $\mathbf{\%}$ & $\mathbf{N}$ \\
\hline \hline $1^{\text {st }}$ Quartile & 35.9 & 3,409 & 28.6 & 3,418 & 25.3 & 3,326 \\
$2^{\text {nd }}$ Quartile & 14.27 & 1,355 & 26.15 & 3,126 & 25.55 & 3,359 \\
$3^{\text {rd }}$ Quartile & 25.4 & 2,412 & 21.28 & 2,543 & 26.06 & 3,426 \\
$4^{\text {th }}$ Quartile & 24.42 & 2,319 & 23.97 & 2,865 & 23.08 & 3,034 \\
Missing & & 5,380 & & 2,923 & & 1,730 \\
Total & 100 & 14,875 & 100 & 14,875 & 100 & 14,875 \\
\hline
\end{tabular}

The second parental status variable is based on the CAMSIS scale. This provides two separate scales for men and women, assuming that social hierarchies vary according to gender. Mothers' and fathers' CAMSIS status scores were derived from their respective SOC90 codes using the conversion table. The measures have been normalized to a 0 to 1 scale using the minimum and maximum of 0 and 100 . Figure 2 illustrates the distribution of mothers' and fathers' CAMSIS scores. Mothers' mean CAMSIS status score is 0.46 (Std. 
Dev. $=0.13)$ compared with fathers' mean score of 0.47 (Std. Dev. $=0.14)$. Using this alternative measure, therefore, fathers and mothers are found to have a very similar level of social status.

Figure 2. Boxplot distribution of Mothers' and Fathers' CAMSIS Status Scores (normalized using observed $\max / \min )$

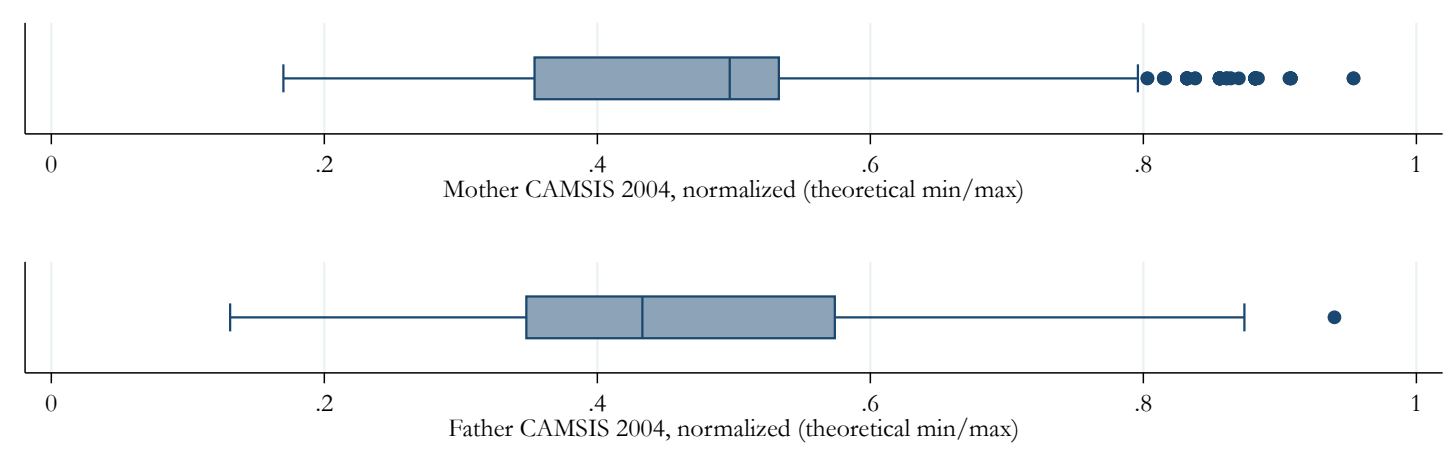

Table 9 presents the quartiles and frequencies taken from the original interval-scale variables, and also gives parental CAMSIS status which has been derived using the dominance approach. The mean score for parental status is 0.50 with standard deviation 0.14 .

Table 9. Distribution of Mothers', Fathers' and Parental CAMSIS Social Status Scores (Quartiles)

\begin{tabular}{lcccccc}
\hline & \multicolumn{2}{c}{ Mothers' Social Status } & \multicolumn{2}{c}{ Fathers' Social Status } & \multicolumn{2}{c}{ Parental Social Status } \\
\cline { 2 - 7 } & $\mathbf{\%}$ & $\mathbf{N}$ & $\mathbf{\%}$ & $\mathbf{N}$ & $\mathbf{\%}$ & $\mathbf{N}$ \\
\hline \hline $1^{\text {st }}$ Quartile & 26.52 & 2,518 & 25 & 2,988 & 25.39 & 3,337 \\
$2^{\text {nd }}$ Quartile & 31.74 & 3,014 & 25.11 & 3,001 & 25.28 & 3,323 \\
$3^{\text {rd }}$ Quartile & 23.39 & 2,221 & 25.46 & 3,043 & 26.2 & 3,444 \\
$4^{\text {th }}$ Quartile & 18.35 & 1,742 & 24.43 & 2,920 & 23.13 & 3,041 \\
Missing & & 5,380 & & 2,923 & & 1,730 \\
Total & 100 & 14,875 & 100 & 14,875 & 100 & 14,875 \\
\hline
\end{tabular}

Table 10 presents Pearson's correlations between the normalised measures of CG and CAMSIS social status described above. 
Table 10. Pearson's Correlations: Mothers', Fathers' and Parental Status Scores (CG and CAMSIS)

\begin{tabular}{|c|c|c|c|c|c|}
\hline & $\begin{array}{l}\text { Mother } \\
\text { (CG) }\end{array}$ & Mother (CAM) & & Father (CG) & Father (CAM) \\
\hline Mother (CG) & 1.00 & & Father (CG) & 1.00 & \\
\hline \multirow[t]{2}{*}{ Mother (CAM) } & $0.89^{* * *}$ & 1.00 & Father (CAM) & $0.87 * * *$ & 1.00 \\
\hline & $\begin{array}{l}\text { Mother } \\
\text { (CG) }\end{array}$ & Father (CG) & & Mother (CAM) & Father (CAM) \\
\hline Mother (CG) & 1.00 & & Mother (CAM) & 1.00 & \\
\hline \multirow[t]{2}{*}{ Father (CG) } & $0.37 * * *$ & 1.00 & Father (CAM) & $0.45^{* * *}$ & 1.00 \\
\hline & & \multicolumn{2}{|c|}{ Parents' Status (CG) } & \multicolumn{2}{|c|}{ Parents' Status (CAM) } \\
\hline \multicolumn{2}{|c|}{ Parents' Status (CG) } & \multicolumn{2}{|c|}{1.00} & \multirow{2}{*}{\multicolumn{2}{|c|}{1.00}} \\
\hline \multicolumn{2}{|c|}{ Parents' Status (CAM) } & \multicolumn{2}{|c|}{$0.88^{* * *}$} & & \\
\hline
\end{tabular}

\section{$5 \quad$ Parental Education}

As is the case for the construction of the parental social class variables and the parental status variables, for the construction of the parental education variables information from Wave 3 (1980) is used, i.e. when children were 10 years old. To minimize missingness, information from a categorical variable as well as a set of dummy variables containing information on the educational attainment of fathers and mothers was used. The level of detail given by these variables allows for a five category variable (see Table 11). This categorization is less fine-grained than the eight category classification used in Bukodi and Goldthorpe (2013), as no differentiation can be made within the O-level category, the A-level category and the Degree category. Details on how the qualifications given in the original variable were reallocated to the present categories are given in the Appendix. The coding routine adopted by Ferdinand Eibel was followed with regards to allocating trade apprentice qualifications to the O-level category. Non-specified qualifications marked as 'other' in the source variable where coded as missing.

The distributions of fathers' and mothers' educational qualifications according to this classification are presented in Table 11. It should be noted that a large proportion of parents (about $39 \%$ of fathers and $54 \%$ of mothers) is shown to have obtained no educational qualification. This number was double checked and corresponds to the values of the source variable (dummy variable c1_9: Father's qualifications: No qualifications), as well as with the distribution found in Bukodi and Goldthorpe (2013). The distribution of the parental education variable using the dominance approach is given in Figure 3 below. 
Table 11. Fathers' and mothers' Highest Educational Qualifications

\begin{tabular}{lcccc}
\hline & \multicolumn{2}{c}{ Fathers } & \multicolumn{2}{c}{ Mothers } \\
\cline { 2 - 5 } & $\mathbf{\%}$ & $\mathbf{N}$ & $\mathbf{\%}$ & $\mathbf{N}$ \\
\hline \hline 1. No qualifications & 38.78 & 4,759 & 53.53 & 6,841 \\
2. O-level / Trade apprentice & 36.12 & 4,433 & 33.87 & 4,329 \\
3. A-level & 9.37 & 1,150 & 3.94 & 503 \\
4. Sub-degree qualification & 2.96 & 363 & 5.74 & 734 \\
5. Degree & 12.77 & 1,567 & 2.92 & 373 \\
Missing & & 2,603 & & 2,095 \\
Total & 100 & 14,875 & 100 & 14875 \\
\hline
\end{tabular}

Figure 3. Distribution of Parental Education (Dominance Approach)

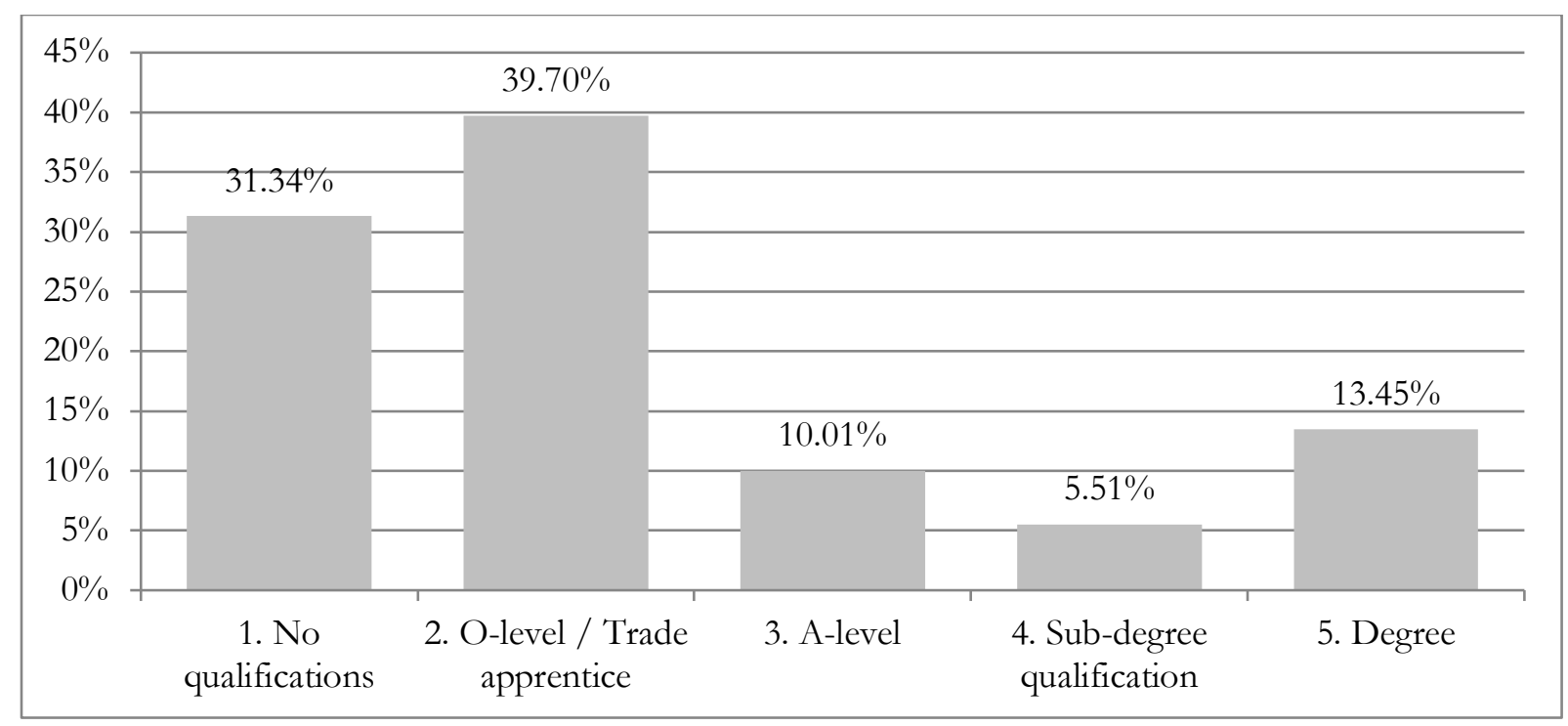

An alternative is to create a combined parental education variable, reflecting the approach taken by Bukodi and Goldthorpe (2013). Information from both parents is incorporated into this composite measure, as reflected in the following categories:

1. Neither parent has any qualification

2. One parent has secondary or lower qualification; other parent has no qualification

3. Both parents have secondary or lower qualification

4. One parent has higher secondary or lower tertiary qualification; other parent has lower qualification

5. Both parents have higher secondary or lower tertiary qualification

6. One parent has degree-level qualification; other parent has lower qualification

7. Both parents have degree-level qualifications

This method requires a plausible assumption to be made regarding missing values if educational information is only available for one parent. For the generation of the composite parental education variable it was assumed that the value of the missing parent equals the modal value for partners corresponding to the valid category. Table 12 shows the distributions for the generated composite parental education measure in comparison with the measure generated by Bukodi and Goldthorpe (2013) with the BCS70 data. As can be seen, there are some differences particularly with regard to categories 2 and 3 . 
Table 12. Parental Education: Composite measure, BSC70

\begin{tabular}{lcc}
\hline & $\begin{array}{c}\text { Generated } \\
\text { variable }\end{array}$ & $\begin{array}{c}\text { Bukodi \& } \\
\text { Goldthorpe 2013 }\end{array}$ \\
\hline \hline $\begin{array}{l}\text { 1. Neither parent has any qualification } \\
\begin{array}{l}\text { 2. One parent has secondary or lower qualification; other } \\
\text { parent has no qualification }\end{array}\end{array}$ & $33.42 \%$ & $33.30 \%$ \\
$\begin{array}{l}\text { 3. Both parents have secondary or lower qualification } \\
\begin{array}{l}\text { 4. One parent has higher secondary or lower tertiary } \\
\text { qualification; other parent has lower qualification }\end{array}\end{array}$ & $19.48 \%$ & $25.60 \%$ \\
$\begin{array}{l}\text { 5. Both parents have higher secondary or lower tertiary } \\
\text { qualification }\end{array}$ & $2.33 \%$ & $13.62 \%$ \\
$\begin{array}{l}\text { 6. One parent has degree-level qualification; other parent } \\
\text { has lower qualification }\end{array}$ & $11.09 \%$ & $13.30 \%$ \\
\begin{tabular}{l} 
7. Both parents have degree-level qualifications \\
\hline
\end{tabular} & $2.15 \%$ & $10.00 \%$ \\
\hline
\end{tabular}

To allow for meaningful cross-cohort comparison of educational attainment, it is useful to treat education in relative terms. To this end scores can be assigned to each category of the composite measure of parental education according to the percentage of parents falling below that level in the cumulative distribution (Bukodi and Goldthorpe, 2013). Table 13 presents the distribution of this relative scale, split into two variables: the first has seven levels and the second has four levels. For the remainder of this data note, the composite measure of parental education is used when parents' educational attainment is referred to.

Table 13. Parental Education: Scores of relative scale (\% falling below given educational level), BCS70

\begin{tabular}{|c|c|c|c|}
\hline 7 levels & 4 levels & Generated variable & Bukodi \& Goldthorpe 2013 \\
\hline 1 & 1 & 0 & 0 \\
\hline 2 & 2 & 33.42 & 32.6 \\
\hline 3 & & 52.9 & 58.4 \\
\hline 4 & 3 & 72.61 & 72.2 \\
\hline 5 & & 84.43 & 85.6 \\
\hline 6 & 4 & 86.75 & 87.9 \\
\hline 7 & & 97.85 & 98.1 \\
\hline \multicolumn{2}{|c|}{ Mean level (7 levels) } & 0.401 & 0.389 \\
\hline \multicolumn{2}{|c|}{ Standard deviation (7 levels) } & 0.333 & 0.326 \\
\hline
\end{tabular}

The mean educational level is calculated by normalising the relative scale variable so that values are within the range 0-1. It should be compared to those found in Bukodi and Goldthorpe (2013) using the earlier cohorts and to the values found for the respondents of the LSYPE survey (born in 1989/1990), listed below.

1946 Cohort: Mean 0.306, Standard deviation 0.371 (Bukodi and Goldthorpe 2013)

1958 Cohort: Mean 0.363, Standard deviation 0.340 (Bukodi and Goldthorpe 2013)

1989/1990 Cohort (LSYPE): Mean 0.400, Standard deviation 0.332 


\section{Parental Income}

The income variable in BCS70 is taken from the age 16 follow-up sweep (1986) and provides information on the combined gross income of the child's mother and father. Respondents were explicitly asked to exclude child benefit, but to include all other earned and unearned income before deductions for tax, national insurance, and so on. Responses were given as either weekly or annual sums. The original variable contained 11 income bands, from which the mid-points were taken. For the top income band $(£, 500+)$, a value of 525 was assigned (this ensured that the amounts increased in equal increments). For each case separately, information on lone-parent status, as well as number of siblings, was used to derive a measure of household composition; this then determined the amount of child benefit entitlement for parents in the year 1986. ${ }^{7}$ The mid-band income and child benefit entitlement amounts were then summed, resulting in a variable with 129 unique income values. Table 14 provides a summary of the variable. Table 15 gives further detail, breaking the distribution down by deciles.

Table 14. BCS70 Constructed Income Variable

\begin{tabular}{ccccc}
\hline Valid N & Mean (SD) & Median & Min & Max \\
6386 & $228.04(122.29)$ & 196.30 & 32.1 & 567.6 \\
\hline
\end{tabular}

Using data from the Effects of Taxes and Benefits on Household Income Survey for the year 1986, summary statistics for gross weekly income are very similar to those reported here:

Mean (SD): $\quad 223.74(191.62)$

Median: $\quad 182.56$

Table 15. BCS70 Constructed Income Variable Deciles

\begin{tabular}{llll}
\hline Percentile & \multicolumn{3}{c}{ Percentile } \\
\hline \hline 10 & 89.2 & 60 & 239.2 \\
20 & 132.1 & 70 & 282.1 \\
30 & 143.8 & 80 & 332.1 \\
40 & 186.7 & 90 & 396.3 \\
50 & 196.3 & 100 & 567.6 \\
\hline
\end{tabular}

Figure 4 presents the frequency distribution of the raw values of the variable and the percentile distribution of the log-transformed values.

7 Source: http://www.ifs.org.uk/ff/childben.xls 
Figure 4. Frequency Distribution (Raw Values) and Percentile Distribution (Log-transformed Values)
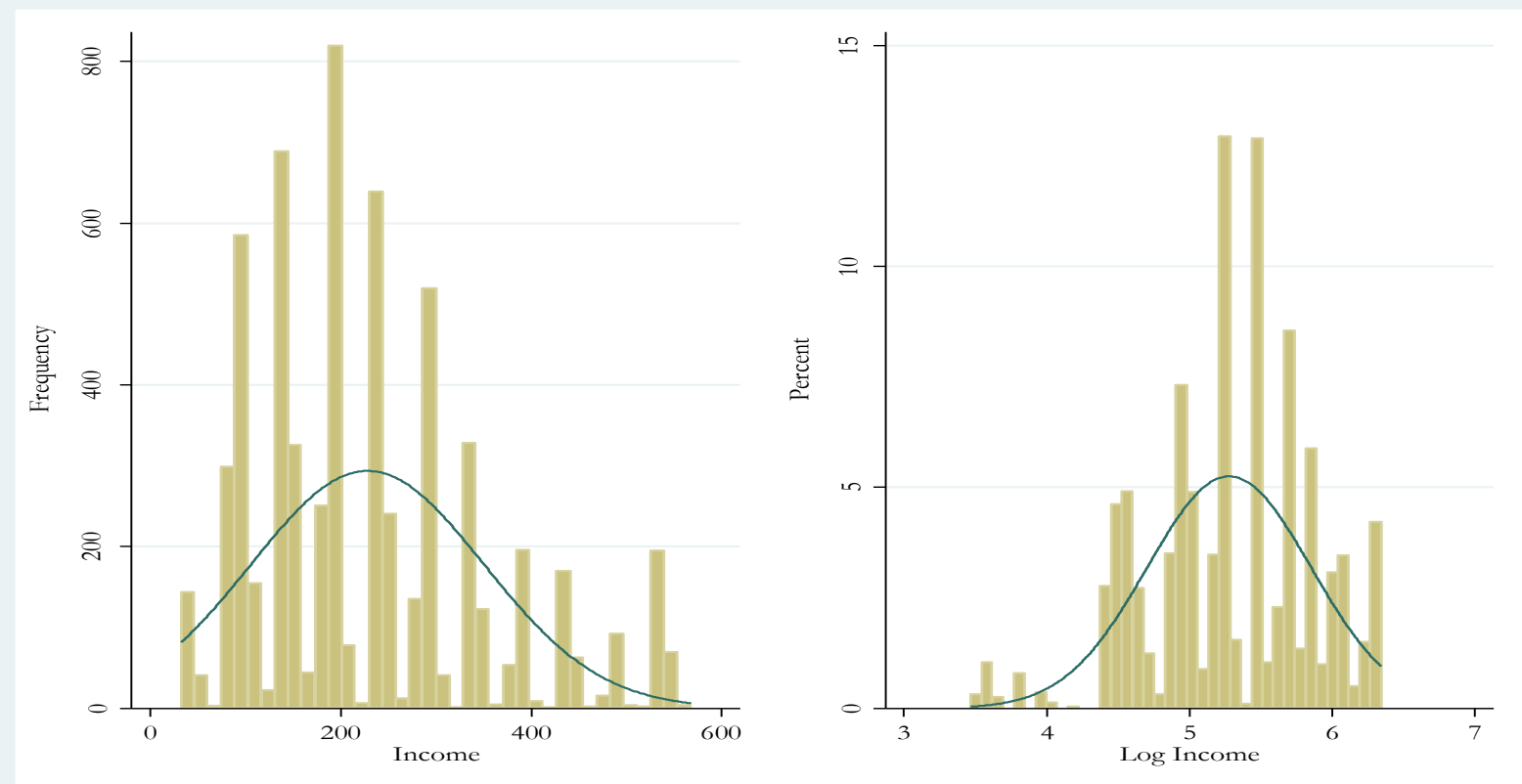

When the parental income variable is transformed to a $0-1$ scale, the measure has a mean of 0.37 with standard deviation $0.23(\mathrm{~N}=6386)$.

\section{$7 \quad$ Cognitive Ability}

A modified version of the British Ability Scales (BAS) was administered to BCS70 respondents at age 10, yielding a number of variables with information on scores for each item of each subtest. This information is used to construct the cognitive ability measure, following, as closely as possible, the approach taken by Schoon $(2010 ; 2008)$ and Bukodi et al (2014). Four BAS subtests are considered: Word Definitions (consisting of 37 individual items), Recall (consisting of 34 individual items), Word Similarities (consisting of 42 paired items) and Matrices (consisting of 28 individual items). For each individual item, cases coded 'no questionnaire' (-6), 'not stated' (-3) or 'no response' (9) were set to missing, those with a correct response (1) were given a value of 1 and those with an incorrect response (2) were given a value of 0 . Questions in the Word Similarities subtest were posed in two parts; for these paired items, cases were given a value of 1 if they correctly answered both parts, and a value of 0 if they answered either one or both parts incorrectly. ${ }^{8}$

The items were then summed to derive an overall score for each of the subtests, and a Principal Components Analysis (PCA) was subsequently run on these four measures. Scores from the first unrotated component extracted were saved for each case, thus providing a measure of each child's cognitive ability otherwise termed ' $\mathrm{g}$ '. The first principal component score accounted for $58 \%$ of the total variance across the four measures. Table 16 presents the factor loadings. 3,480 of the original 14,875 cases are missing information on this measure.

\footnotetext{
${ }^{8}$ See file:///C:/Users/BourneM/Downloads/British\%20Ability $\% 20$ Scale $\% 20$ Totals $\% 20(1)$.pdf from the Centre for Longitudinal Studies (CLS) website, which recommends treating the measures in this way.
} 
Table 16. PCA to Derive Cognitive Ability Measure

\begin{tabular}{|c|c|c|c|c|c|c|c|c|c|}
\hline \multicolumn{6}{|c|}{ PCA } & \multicolumn{4}{|c|}{ New Variable } \\
\hline Eigenvalue & & & ding & & $\begin{array}{c}\% \text { of } \\
\text { variance }\end{array}$ & Min & Max & Mean (SD) & $\mathrm{N}$ \\
\hline & Word Def & Recall & Word Sim & Matrices & & & & & \\
\hline 2.31 & 0.55 & 0.39 & 0.55 & 0.49 & $58 \%$ & -5.64 & 5.13 & $0.00(1.52)$ & 11,395 \\
\hline
\end{tabular}

Figure 5 presents the percentile distribution of the cognitive ability variable. Table 17 presents quintiles.

Figure 5. Distribution of Cognitive Ability

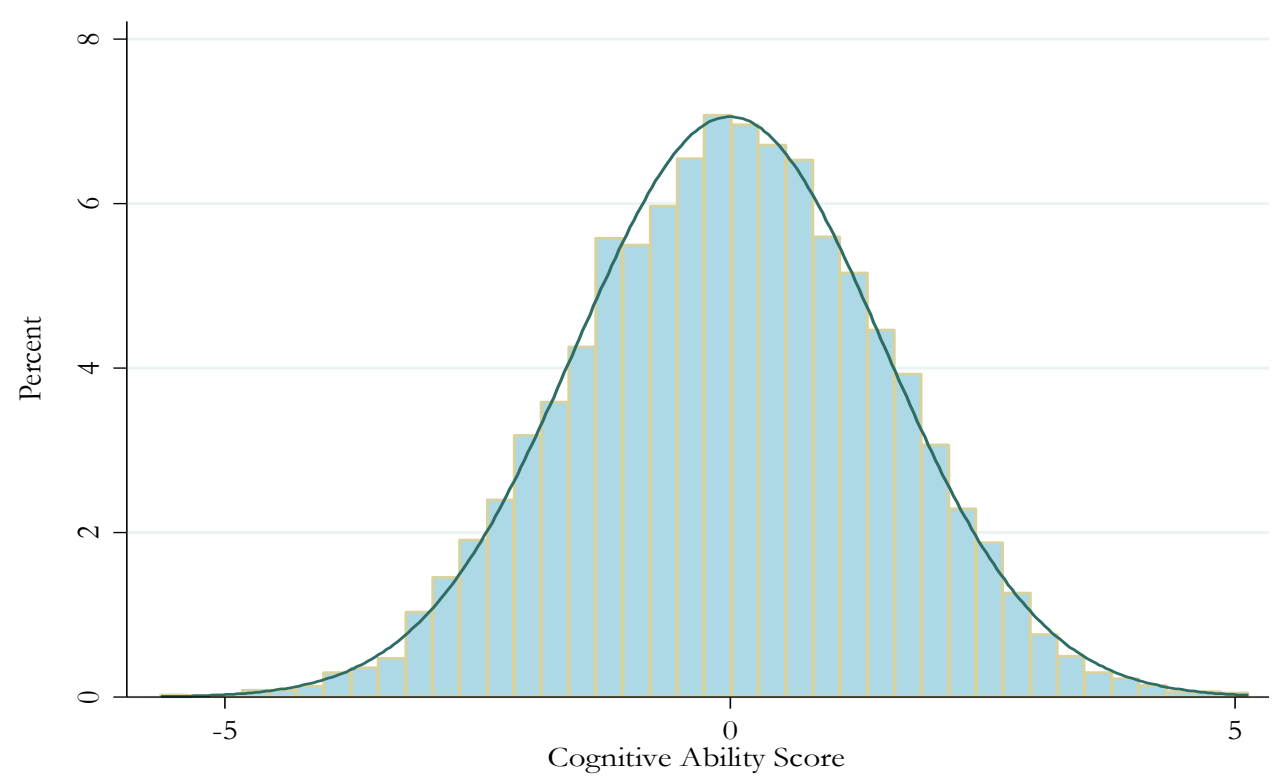

Table 17. Quintiles of Cognitive Ability

\begin{tabular}{lcc}
\hline & $\mathbf{\%}$ & $\mathbf{N}$ \\
\hline \hline $1^{\text {st }}$ Quintile (Lowest) & 20 & 2279 \\
$2^{\text {nd }}$ Quintile & 20 & 2279 \\
$3^{\text {rd }}$ Quintile & 20 & 2279 \\
$4^{\text {th }}$ Quintile & 20 & 2280 \\
$5^{\text {th }}$ Quintile (Highest) & 20 & 2278 \\
Missing & -- & 3480 \\
Total & 100 & 14875 \\
\hline
\end{tabular}

\section{Respondent Educational Attainment}

This section provides an overview of the key aspects of respondent's educational attainment that will be used in the analysis for the research project. In order to allow for comparison with the other data notes compiled for the project, the descriptives for respondent educational attainment are shown for both age 20 and age 38. Table 18 and Table 19 report the distribution of the measure of the highest level of education achieved by age 20 and 38 . 
Table 18. Highest educational qualification at age 20

\begin{tabular}{lrr}
\hline & \% & \multicolumn{1}{c}{$\mathbf{N}$} \\
\hline \hline [1] No qualifications & 24.28 & 2,947 \\
[2] Below O-level, NVQ 1 [Sub-secondary] & 8.22 & 998 \\
[3] 1-4 O-level passes, NVQ 2 [Secondary_low performance] & 21.55 & 2,616 \\
[4] 5+ O-level passes or 1 A-level pass, NVQ 3 [Secondary_high perf.] & 25.62 & 3,110 \\
[5] 2+ A-level passes [Higher secondary] & 13.85 & 1,681 \\
[6] Tertiary sub-degree qualification, NVQ 4 [Lower tertiary] & 6.43 & 780 \\
[7] Degree, NVQ5 or 6, higher degree [Higher tertiary] & 0.04 & 5 \\
Missing & & 0 \\
Total & & 12,137
\end{tabular}

Table 19. Highest educational qualification at age 38

\begin{tabular}{lrr}
\hline & $\mathbf{\%}$ & \multicolumn{1}{c}{$\mathbf{N}$} \\
\hline \hline [1] No qualifications & 14.07 & 1,708 \\
[2] Below O-level, NVQ 1 [Sub-secondary] & 7.62 & 925 \\
[3] 1-4 O-level passes, NVQ 2 [Secondary-low performance] & 20.86 & 2,532 \\
[4] 5+ O-level passes or 1 A-level pass, NVQ 3 [Secondary—-high performance] & 21.04 & 2,554 \\
[5] 2+ A-level passes [Higher secondary] & 2.64 & 320 \\
[6] Tertiary sub-degree qualification, NVQ 4 [Lower tertiary] & 14.49 & 1,759 \\
[7] Degree, NVQ5 or 6, higher degree [Higher tertiary] & 19.27 & 2,339 \\
Missing & & 0 \\
Total & & 12,137
\end{tabular}

Table 20 and 21 show the percentage of cohort members who have passed two or more A-Level qualifications by age 20 and 38 respectively. Table 22 and 23 show the percentage of cohort members who have passed two or more A-Level qualifications or the vocational equivalent by age 20 and 38 respectively. Table 24 cross-tabulates the level of educational qualification attained at age 20 and the measure for crossing the KS5 threshold by age 20 .

Table 20. Passing of Threshold at Key Stage 5 by age 20 (academic only)

\begin{tabular}{lcc}
\hline & $\mathbf{\%}$ & $\mathbf{N}$ \\
\hline \hline No & 81.68 & 9,914 \\
Yes & 18.32 & 2,223 \\
\hline Missing & & 0 \\
Total & 100.00 & 12,137
\end{tabular}

Table 21. Passing of Threshold at Key Stage 5 by age 38 (academic only)

\begin{tabular}{lcc}
\hline & $\mathbf{\%}$ & $\mathbf{N}$ \\
\hline \hline No & 69.11 & 8,388 \\
Yes & 30.89 & 3,749 \\
\hline Missing & & 0 \\
Total & 100.00 & 12,137
\end{tabular}


Table 22. Passing of Threshold at Key Stage 5 by age 20 (academic \& vocational)

\begin{tabular}{lcc}
\hline & $\mathbf{\%}$ & $\mathbf{N}$ \\
\hline \hline No & 79.68 & 9,671 \\
Yes & 20.32 & 2,466 \\
\hline Missing & & 0 \\
Total & 100.00 & 12,137
\end{tabular}

Table 23. Passing of Threshold at Key Stage 5 by age 38 (academic \& vocational)

\begin{tabular}{lcc}
\hline & $\mathbf{\%}$ & $\mathbf{N}$ \\
\hline \hline No & 63.60 & 7,719 \\
Yes & 36.40 & 4,418 \\
\hline Missing & & 0 \\
Total & 100.00 & 12,137
\end{tabular}

Table 24. Crosstab of highest educational qualification at age 20 and passing of KS5 Threshold (academic and vocational)

\begin{tabular}{|c|c|c|c|}
\hline & \multicolumn{3}{|c|}{ Transition to KS 5} \\
\hline & $\mathrm{No}$ & Yes & Total \\
\hline \multirow[t]{3}{*}{ 1. No qualifications } & 2,693 & 0 & 2,693 \\
\hline & $100.00 \%$ & $0.00 \%$ & $100.00 \%$ \\
\hline & $44.51 \%$ & $0.00 \%$ & $24.06 \%$ \\
\hline \multirow[t]{3}{*}{ 2. Below O-level, NVQ 1 [Sub-secondary] } & 909 & 0 & 909 \\
\hline & $100.00 \%$ & $0.00 \%$ & $100.00 \%$ \\
\hline & $15.02 \%$ & $0.00 \%$ & $8.12 \%$ \\
\hline \multirow[t]{3}{*}{ 3. 1-4 O-level passes, NVQ2 [Secondary—low performance] } & 2,448 & 0 & 2,448 \\
\hline & $100.00 \%$ & $0.00 \%$ & $100.00 \%$ \\
\hline & $40.46 \%$ & $0.00 \%$ & $21.87 \%$ \\
\hline \multirow{3}{*}{$\begin{array}{l}\text { 4. } 5+\text { O-level passes or } 1 \text { A-level pass, NVQ } 3 \text { [Secondary-high } \\
\text { performance] }\end{array}$} & 0 & 2,875 & 2,875 \\
\hline & $0.00 \%$ & $100.00 \%$ & $100.00 \%$ \\
\hline & $0.00 \%$ & $55.89 \%$ & $25.68 \%$ \\
\hline \multirow[t]{3}{*}{ 5. 2+ A-level passes [Higher secondary] } & 0 & 1,553 & 1,553 \\
\hline & $0.00 \%$ & $100.00 \%$ & $100.00 \%$ \\
\hline & $0.00 \%$ & $30.19 \%$ & $13.87 \%$ \\
\hline \multirow[t]{3}{*}{ Tertiary sub-degree qualification, NVQ 4 [Lower tertiary] } & 0 & 711 & 711 \\
\hline & $0.00 \%$ & $100.00 \%$ & $100.00 \%$ \\
\hline & $0.00 \%$ & $13.82 \%$ & $6.35 \%$ \\
\hline \multirow[t]{3}{*}{ Degree, NVQ 5 or 6 , higher degree [Higher tertiary] } & 0 & 5 & 5 \\
\hline & $0.00 \%$ & $100.00 \%$ & $100.00 \%$ \\
\hline & $0.00 \%$ & $0.10 \%$ & $0.04 \%$ \\
\hline \multirow[t]{3}{*}{ Total } & 6,050 & 5,144 & 11,194 \\
\hline & $54.05 \%$ & $45.95 \%$ & $100.00 \%$ \\
\hline & $100.00 \%$ & $100.00 \%$ & $100.00 \%$ \\
\hline
\end{tabular}

An additional measure was generated indicating whether cohort members have crossed the Higher Education threshold. Table 25 shows the proportion of individuals who have crossed the threshold by age 
38. Here the threshold is operationalized so that individuals with sub-degrees are not counted as having made the transition. Table 26 shows the distribution when the measure includes sub-degrees. Tables 27 and 28 show the proportion of individuals who have crossed the threshold, again including and excluding individuals with sub-degrees respectively, but also counting the vocational qualifications at the (sub-)degree level. Table 29 cross-tabulates the level of educational qualification attained at age 38 and the measure for crossing the Higher Education threshold by age 38 (excluding sub-degree).

Table 25. Transition to Higher Education by age 38 (academic only), excluding sub-degree

\begin{tabular}{lcc}
\hline & $\mathbf{\%}$ & $\mathbf{N}$ \\
\hline \hline No & 81.21 & 9,857 \\
Yes & 18.79 & 2,280 \\
\hline Missing & & 0 \\
Total & 100.00 & 12,137
\end{tabular}

Table 26. Transition to Higher Education by age 38 (academic only), including sub-degree

\begin{tabular}{lcc}
\hline & $\mathbf{\%}$ & $\mathbf{N}$ \\
\hline \hline No & 72.26 & 8,770 \\
Yes & 27.74 & 3,367 \\
\hline Missing & & 0 \\
Total & 100.00 & 12,137
\end{tabular}

Table 27. Transition to Higher Education by age 38 (academic \& vocational), excluding sub-degree

\begin{tabular}{lcc}
\hline & $\mathbf{\%}$ & $\mathbf{N}$ \\
\hline \hline No & 80.73 & 9,798 \\
Yes & 19.27 & 2,339 \\
\hline Missing & & 0 \\
Total & 100.00 & 12,137
\end{tabular}

Table 28. Transition to Higher Education by age 38 (academic \& vocational), including sub-degree

\begin{tabular}{lcc}
\hline & $\mathbf{\%}$ & $\mathbf{N}$ \\
\hline \hline No & 66.24 & 8,039 \\
Yes & 33.76 & 4,098 \\
\hline Missing & & 0 \\
Total & 100.00 & 12,137
\end{tabular}


Table 29. Crosstab of highest educational qualification at age 38 and transition to HE (academic \& vocational), excluding sub-degree

\begin{tabular}{lccc}
\hline & \multicolumn{3}{c}{ Transition to KS 5 } \\
\cline { 2 - 4 } & No & Yes & Total \\
\hline \hline 1. No qualifications & 1,549 & 0 & 1,549 \\
& $100.00 \%$ & $0.00 \%$ & $100.00 \%$ \\
& $17.13 \%$ & $0.00 \%$ & $13.84 \%$ \\
2. Below O-level, NVQ 1 [Sub-secondary] & 850 & 0 & 850 \\
& $100.00 \%$ & $0.00 \%$ & $100.00 \%$ \\
3. 1-4 O-level passes, NVQ2 [Secondary-low performance] & $9.40 \%$ & $0.00 \%$ & $7.59 \%$ \\
& 2,361 & 0 & 2,361 \\
4. 5+ O-level passes or 1 A-level pass, NVQ 3 [Secondary-high & $100.00 \%$ & $0.00 \%$ & $100.00 \%$ \\
performance] & $26.11 \%$ & $0.00 \%$ & $21.09 \%$ \\
& 2,364 & 0 & 2,364 \\
5. 2+ A-level passes [Higher secondary] & $100.00 \%$ & $0.00 \%$ & $100.00 \%$ \\
& $26.14 \%$ & $0.00 \%$ & $21.12 \%$ \\
& 296 & 0 & 296 \\
Tertiary sub-degree qualification, NVQ 4 [Lower tertiary] & $100.00 \%$ & $0.00 \%$ & $100.00 \%$ \\
& $3.27 \%$ & $0.00 \%$ & $2.64 \%$ \\
\hline & 1,624 & 0 & 1,624 \\
Degree, NVQ 5 or 6, higher degree [Higher tertiary] & $100.00 \%$ & $0.00 \%$ & $100.00 \%$ \\
& $17.96 \%$ & $0.00 \%$ & $14.51 \%$ \\
& 0 & 2,150 & 2,150 \\
& $0.00 \%$ & $100.00 \%$ & $100.00 \%$ \\
& $0.00 \%$ & $100.00 \%$ & $19.21 \%$ \\
& 9,044 & 2,150 & 11,194 \\
& $80.79 \%$ & $19.21 \%$ & $100.00 \%$ \\
& $100.00 \%$ & $100.00 \%$ & $100.00 \%$ \\
\hline
\end{tabular}

The measures of performance at Key Stage 4 is operationalized as the number of GCSE/O-Level/CSE qualifications attained at grades $A^{*}-\mathrm{C}$. The measure of performance at Key Stage 5 is operationalized as the number of A-levels passed. Both measures were generated using information from BCS70 Wave 5 when cohort members where 26 years old, since no earlier information is available. Information from Wave 4 cannot be used for this purpose, since a large number of cohort members had not yet completed their lower secondary exams at the time they were questioned. Observations with missing information in Wave 5 were coded using information from later waves, where available. As a consequence, the measures of KS4 and KS5 performance also include GCSE/O-Level/CSE and A-Level qualifications that were attained after the 'normal' time at which lower/upper secondary level qualifications are taken. 
Table 30. Performance lower sec. level - Number of GCSE/GNVQ Qualifications at Grades A*_C

\begin{tabular}{ccc} 
& $\%$ & $\mathbf{N}$ \\
\hline \hline 0 & 24.46 & 2206 \\
2 & 9.62 & 868 \\
3 & 8.85 & 798 \\
4 & 7.54 & 680 \\
5 & 7.44 & 671 \\
6 & 7.57 & 683 \\
7 & 6.92 & 624 \\
8 & 6.06 & 547 \\
9 & 7.28 & 657 \\
10 & 6.03 & 544 \\
11 & 4.16 & 375 \\
12 & 2.18 & 197 \\
13 & 1.14 & 103 \\
14 & 0.41 & 37 \\
15 & 0.11 & 10 \\
16 & 0.07 & 6 \\
17 & 0.09 & 8 \\
Missing & 0.06 & 5 \\
Total & - & 5856 \\
& $100.00 \%$ & 14875 \\
\hline & &
\end{tabular}

Table 31. Performance upper sec. level - Number of A-levels Passed

\begin{tabular}{ccc} 
& \% & $\mathbf{N}$ \\
\hline \hline 0 & 5,278 & 66.03 \\
1 & 492 & 6.16 \\
2 & 632 & 7.91 \\
3 & 972 & 12.16 \\
4 & 427 & 5.34 \\
5 & 106 & 1.33 \\
6 & 33 & 0.41 \\
7 & 27 & 0.34 \\
8 & 16 & 0.2 \\
9 & 7 & 0.09 \\
10 & 2 & 0.03 \\
11 & 1 & 0.01 \\
\hline Missing & - & 6,882 \\
Total & $100.00 \%$ & 14,875
\end{tabular}


Figure 6. Performance at lower sec. level — Number of GCSE/GNVQ qualifications at grades A* - C

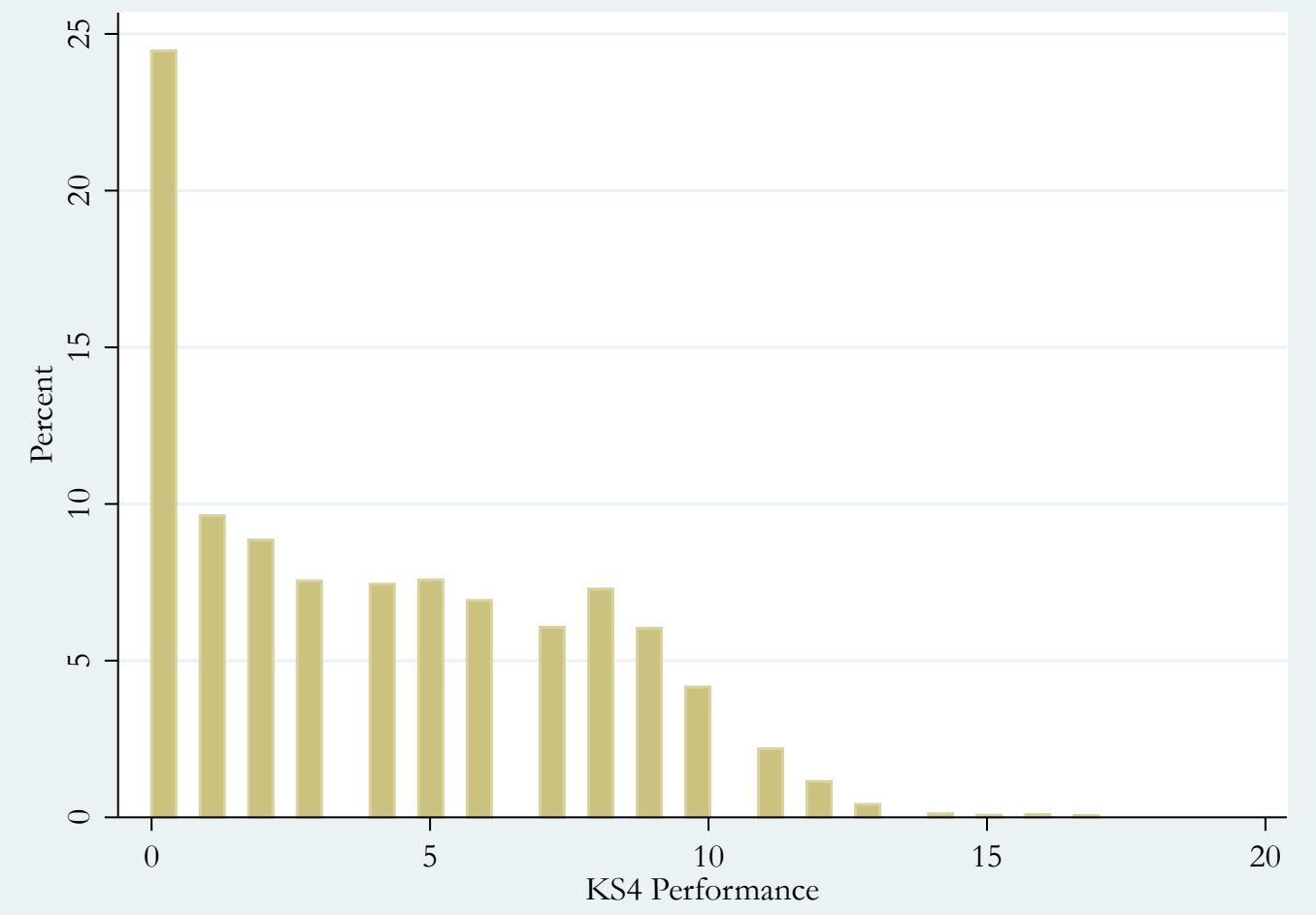

Figure 7. Performance at upper secondary level — Number of A levels passed

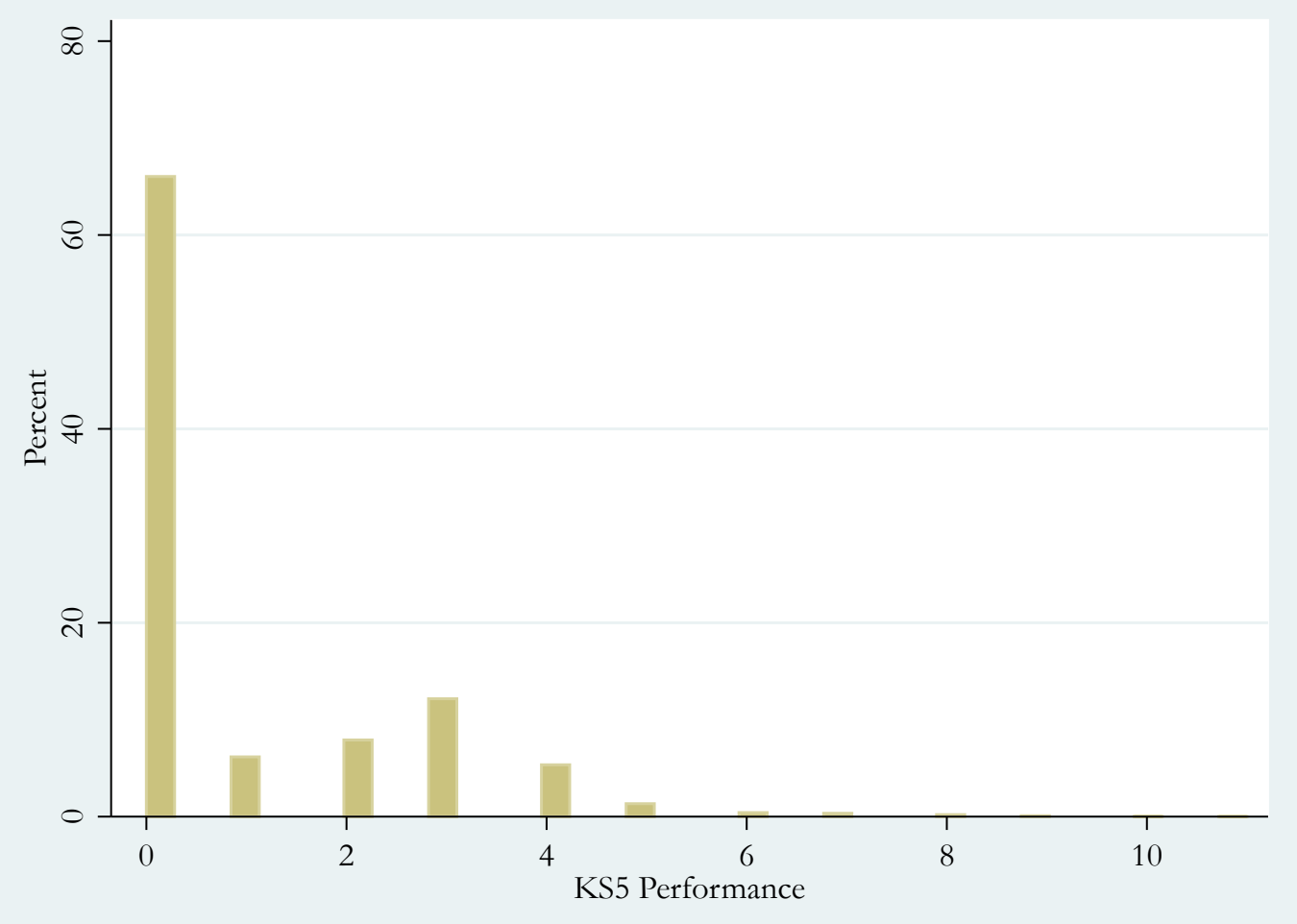




\section{Associations between Social Origin Measures}

This section presents the results from a series of bivariate analyses between the social origin measures. First, the parental CG status score variable (original scale) is considered in terms of its distribution across parental social class (see Figure 8 and Table 32).

Figure 8. Boxplot Distribution of Parental CG Status Scores by Parental Class

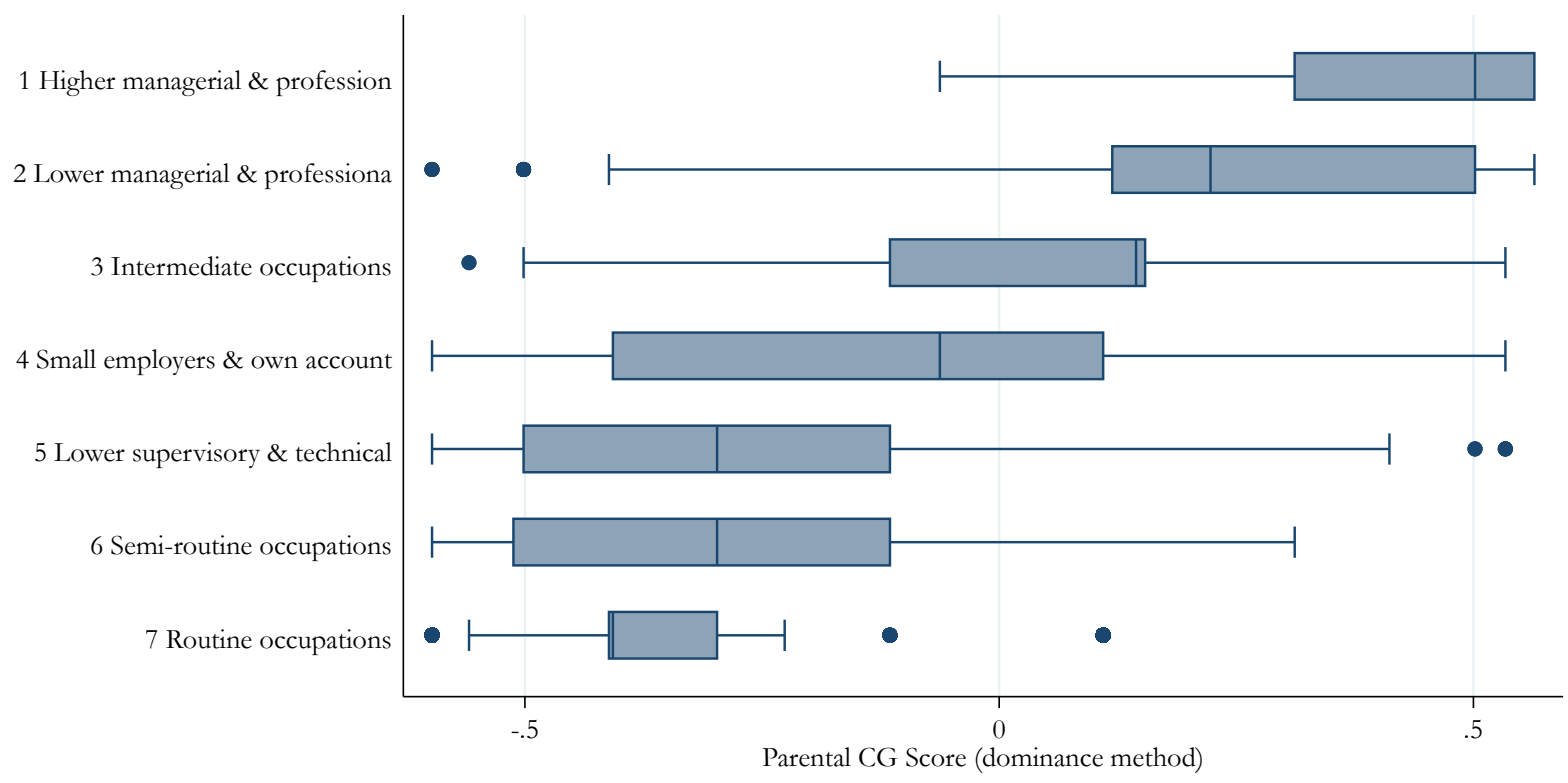

Table 32. Mean Parental CG Status Scores by Parental Class

\begin{tabular}{lccc}
\hline NS-SEC (reduced method) & Mean & Std. Dev. & Freq. \\
\hline \hline 1. Higher managerial & 0.36 & 0.22 & 1435 \\
2. Lower managerial & 0.24 & 0.22 & 2848 \\
3. Intermediate & 0.07 & 0.21 & 1169 \\
4. Small employers & -0.13 & 0.26 & 1682 \\
5. Lower supervisory & -0.26 & 0.25 & 2368 \\
6. Semi routine & -0.30 & 0.21 & 1757 \\
7. Routine & -0.34 & 0.21 & 1886 \\
Total & -0.06 & 0.34 & 13145 \\
\hline
\end{tabular}

Table 33 presents the results of a one-way analysis of variance, showing that the differences between groups are statistically significant $(\mathrm{F}=2793.30, \mathrm{p}<0.01)$ and that $56 \%$ of the total variance in parental status is explained by parental class. For the purpose of comparison, note that in the LSYPE data $52 \%$ of the total variance in parental status is explained by parental class (see LSYPE Data Note).

Table 33. One-way ANOVA: Parental Status by Parental Class

\begin{tabular}{ccccc}
\hline Between groups & Within groups & $F$ & $p$ & $\%$ \\
\hline \hline 875.83 & 686.56 & 2793.30 & 0.000 & 56 \\
\hline Notes: \% denotes the percentage of total variance in status explained by social class & & &
\end{tabular}

Table 36 uses the 7-level relative scale parental education variable (normalised with range $0-1$ ) to present the mean level of parental education for each social-class group. 
Table 34. Mean Parental Education (7-level Relative Scale, Normalised) by Parental Class

\begin{tabular}{lccc}
\hline NS-SEC (reduced method) & Mean & Std. Dev. & Freq. \\
\hline \hline 1. Higher managerial & 0.77 & 0.24 & 1425 \\
2. Lower managerial & 0.59 & 0.30 & 2823 \\
3. Intermediate & 0.43 & 0.28 & 1156 \\
4. Small employers & 0.38 & 0.29 & 1654 \\
5. Lower supervisory & 0.33 & 0.27 & 2320 \\
6. Semi routine & 0.20 & 0.25 & 1714 \\
7. Routine & 0.15 & 0.23 & 1839 \\
Total & 0.41 & 0.33 & 12931 \\
\hline
\end{tabular}

Table 35 gives the results of a one-way analysis of variance, showing that the differences in the mean educational level between social-class groups are statistically significant $(F=1119.61, p<0.01)$ and $34 \%$ of the total variance in parental education is explained by parental class. For the purpose of comparison, note that in the LSYPE data 33\% of the total variance in parental education is explained by parental class (see LSYPE Data Note).

Table 35. One-way ANOVA: Parental Education by Parental Class

\begin{tabular}{ccccc}
\hline Between groups & Within groups & $F$ & $p$ & $\%$ \\
\hline \hline 488.65 & 940.11 & 1119.61 & 0.000 & 34 \\
\hline
\end{tabular}

Note: $\%$ denotes the percentage of total variance in status explained by social class

A cross-tabulation between parental class and education is given in Table 55 in the Appendix, which uses the composite parental education variable (i.e., not relativized/not normalised). Figure 9 below provides a cruder summary of the relationship by comparing the proportion of cases for which: (i) neither parent has any qualifications, and (ii) at least one parent has a degree-level qualifications, by social-class. It is important to note that the operationalization of category (ii) differs from the definition used in the LSYPE data note. In the latter it is defined as 'both parents have a degree-level qualifications'. This definition was note appropriate for the purpose of showing the distribution in BCS70, since this extreme category (category 7 ) had too few observations (see Table 57). Thus category 6 and 7 of the composite measure of parental education were combined. 
Figure 9. Proportion of Cases: (i) Neither Parent has Any Qualifications, and (ii) At least one parent has a Degree-Level Qualifications, by Parental Class

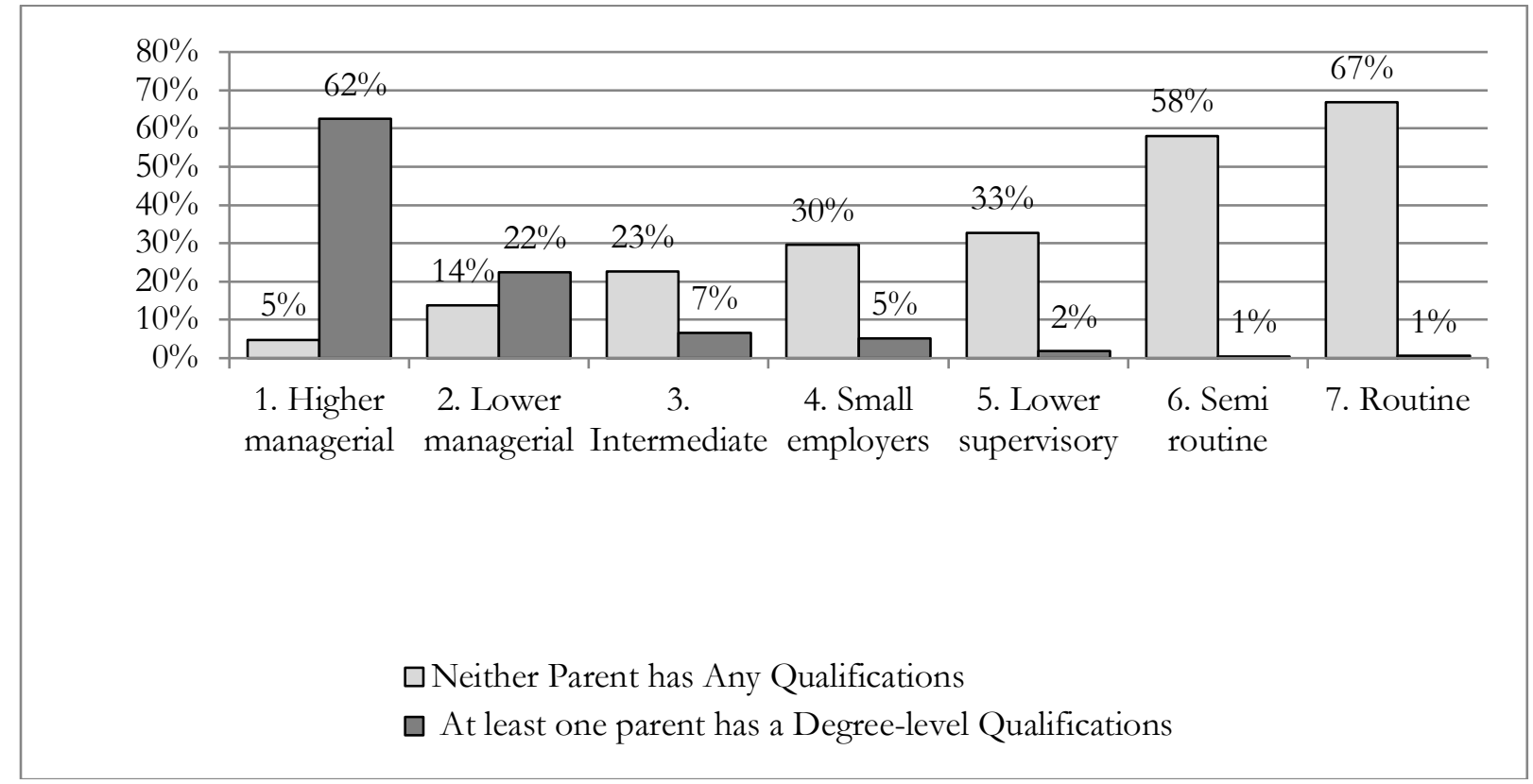

Figure 10 shows how the parental status variable is distributed within each of the seven groups of the composite parental education variable. As expected, those with higher status scores tend to have higher levels of education.

Figure 10. Boxplot Distribution of Parental CG Status Scores (Original Scale) by Parental Education (Composite measure)

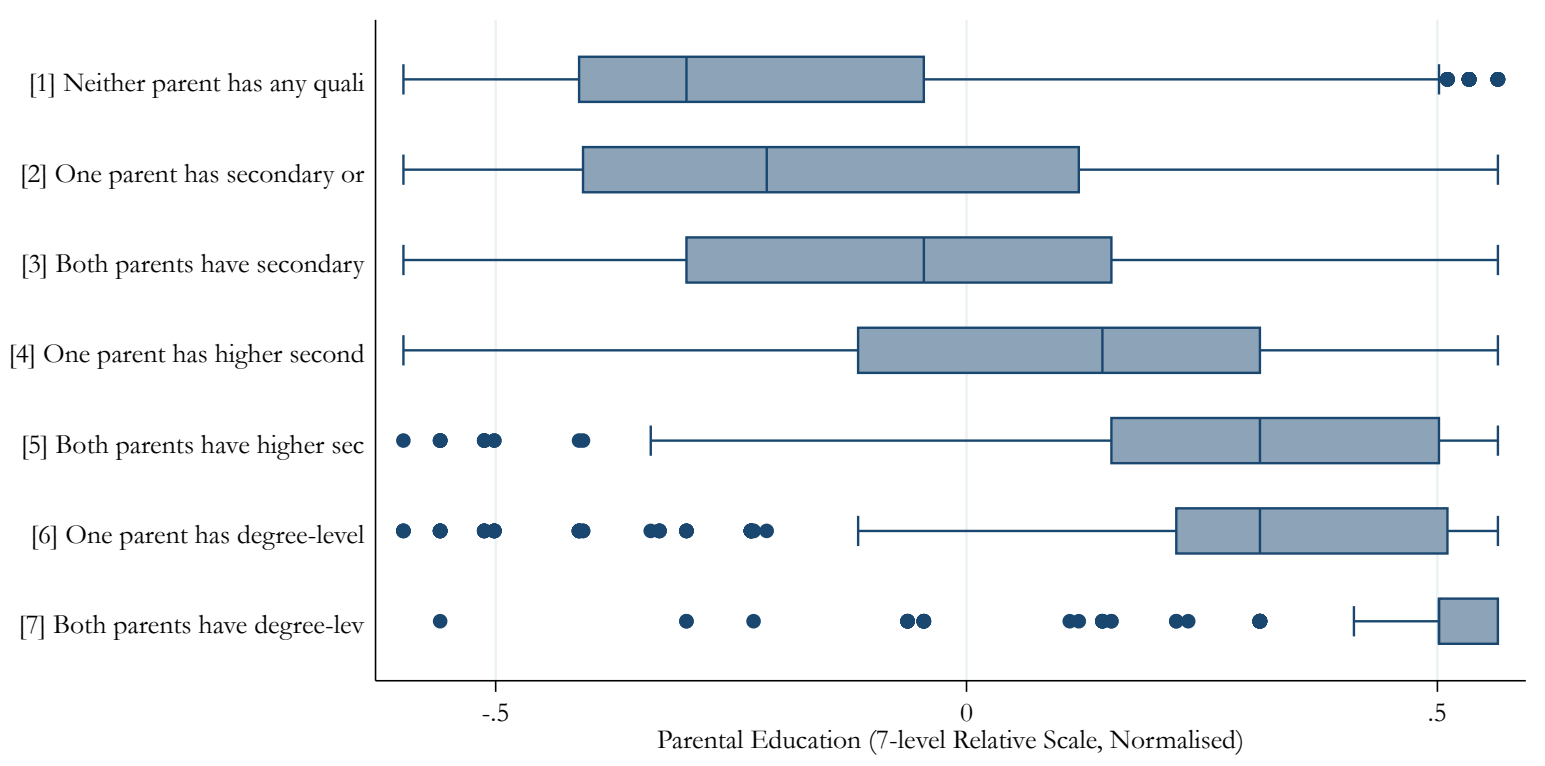

Table 36 uses the CG status quartiles variable to examine the relationship between parental status and parental education. Table 37 gives the mean, median and standard deviations of parental income by each category of parental class, status and education. 
Table 36. Cross-tabulation of CG Parental Status Quartiles and Parental Education (Composite measure)

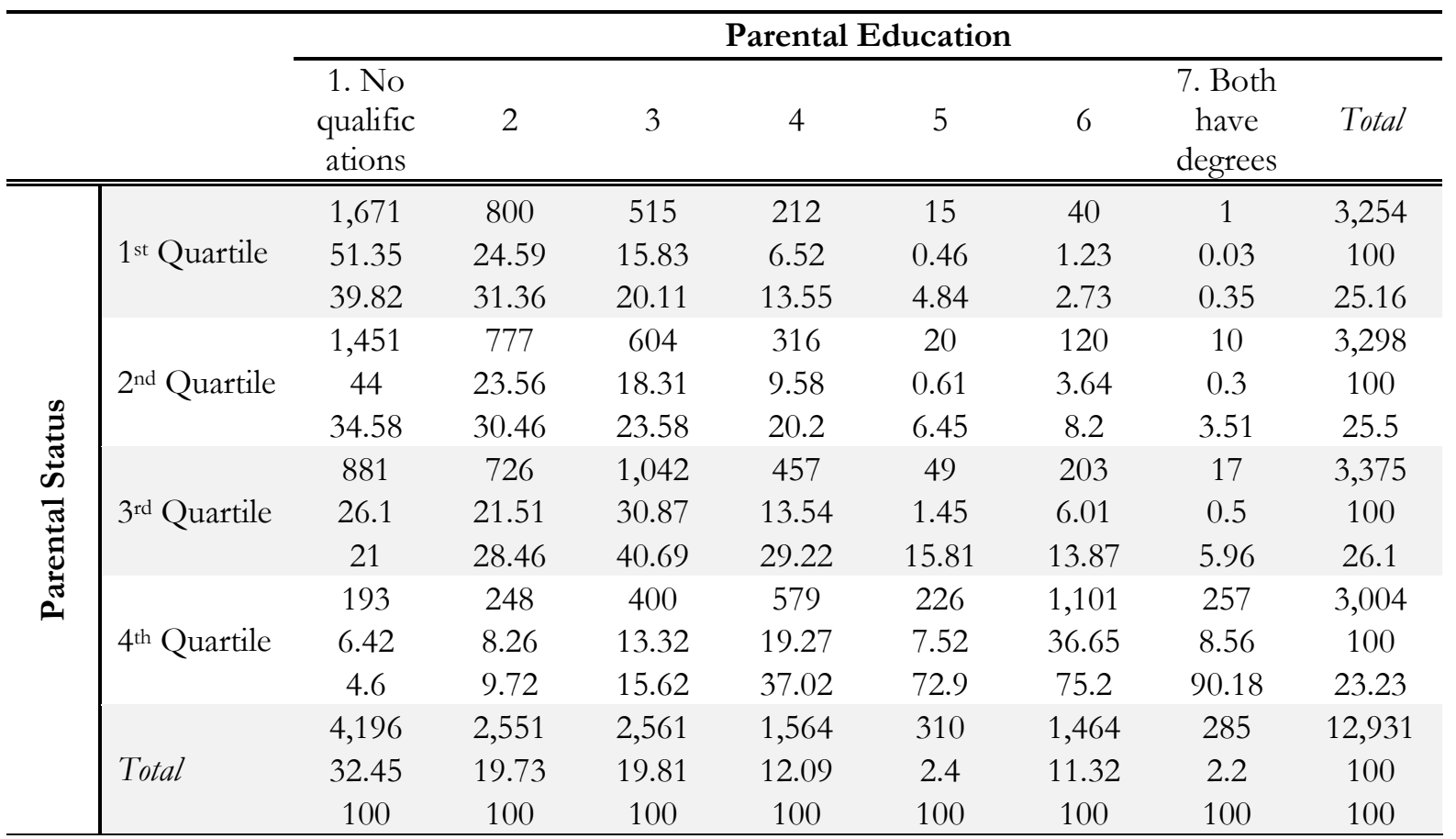

Note: First row $=$ Frequencies; Second row $=$ Row percentages; Third row $=$ Column percentages

Table 37. Parental Income by Parental Class, CG Status Quartiles and Education (Composite measure)

\begin{tabular}{|c|c|c|c|c|c|c|c|}
\hline & \multicolumn{6}{|c|}{ Parental Income } \\
\hline & & Median & Mean & $\mathrm{SD}$ & Min & Max & $\mathrm{N}$ \\
\hline \multirow{7}{*}{$\begin{array}{c}\text { Parental } \\
\text { Class }\end{array}$} & Higher managerial & 339.2 & 357.6 & 129.4 & 32.1 & 567.6 & 663.0 \\
\hline & Lower managerial & 289.2 & 285.9 & 123.1 & 32.1 & 560.5 & 1398.0 \\
\hline & Intermediate & 232.1 & 228.0 & 103.5 & 36.7 & 546.3 & 545.0 \\
\hline & Small employers & 196.3 & 223.7 & 112.8 & 32.1 & 560.5 & 594.0 \\
\hline & Lower supervisory & 189.2 & 196.7 & 86.9 & 32.1 & 558.0 & 1069.0 \\
\hline & Semi Routine & 153.4 & 171.2 & 81.5 & 32.1 & 546.3 & 777.0 \\
\hline & Routine & 139.2 & 152.2 & 72.5 & 32.1 & 539.2 & 825.0 \\
\hline \multirow{4}{*}{$\begin{array}{c}\text { Parental } \\
\text { Status }\end{array}$} & $1^{\text {st }}$ Quartile & 153.4 & 173.4 & 83.3 & 32.1 & 558.0 & 1414.0 \\
\hline & $2^{\text {nd }}$ Quartile & 189.2 & 199.7 & 101.8 & 32.1 & 553.4 & 1447.0 \\
\hline & $3^{\text {rd }}$ Quartile & 208.0 & 231.3 & 112.1 & 32.1 & 560.5 & 1543.0 \\
\hline & $4^{\text {th }}$ Quartile & 296.3 & 321.6 & 130.2 & 32.1 & 567.6 & 1467.0 \\
\hline \multirow{7}{*}{$\begin{array}{c}\text { Parental } \\
\text { Education }\end{array}$} & 1. No qual. & 146.3 & 163.6 & 83.2 & 32.1 & 560.5 & 1907.0 \\
\hline & 2 & 189.2 & 205.2 & 97.8 & 32.1 & 546.3 & 1140.0 \\
\hline & 3 & 232.1 & 230.5 & 101.5 & 32.1 & 558.0 & 1186.0 \\
\hline & 4 & 250.9 & 274.3 & 120.2 & 36.7 & 560.5 & 770.0 \\
\hline & 5 & 339.2 & 338.1 & 125.4 & 39.2 & 553.4 & 140.0 \\
\hline & 6 & 339.2 & 344.1 & 127.0 & 32.1 & 567.6 & 712.0 \\
\hline & 7. Both w/ degrees & 439.2 & 404.0 & 130.7 & 86.7 & 553.4 & 140.0 \\
\hline
\end{tabular}


Table 38 presents the results of a one-way analysis of variance, showing that the differences between groups are statistically significant $(\mathrm{F}<0371.89, \mathrm{p}<0.01)$ and that $28 \%$ of the total variance in parental income is explained by parental class.

Table 38. One-way ANOVA: Parental Income by Parental Class

\begin{tabular}{ccccc}
\hline Between groups & Within groups & $F$ & $p$ & $\%$ \\
\hline \hline 24029428.2 & 63150117.2 & 371.89 & 0.000 & 28 \\
\hline
\end{tabular}

Notes: \% denotes the percentage of total variance in status explained by social class

Finally, correlations between the social origin variables are presented below. Table 39 gives Spearman rank correlations between categorical measures. Table 40 gives Pearson correlations between alternative social origin measures, all of which have been normalised to take values in the range $0-1$. The strength of associations is largely similar across the two tables. All correlations are statistically significant $(p<0.01)$. Parental class and status are strongly correlated, correlations between parental education and class or status are moderate, and correlations between parental income and any other social origin measure are comparatively weak.

Table 39. Spearman Rank Correlations: Parental Class, CG Status Quartiles, Education (Composite Measure) and Income Quartiles

\begin{tabular}{lcccc}
\hline & Class & Education & Status & Income \\
\hline \hline Class & $1.00^{* *}$ & & & \\
Education & $0.59^{* *}$ & $1.00^{* *}$ & & \\
Status & $0.72^{* *}$ & $0.55^{* *}$ & $1.00^{* *}$ & \\
Income & $0.48^{* *}$ & $0.49^{* *}$ & $0.41^{* *}$ & $1.00^{* *}$ \\
\hline
\end{tabular}

Notes: Values have been reversed so that lower values indicate a lower status/class/education category

Table 40. Pearson Correlations: Parental Class, CG Status (Original Scale), Education (Composite Measure and Relative Scale) and Income (Original Scale)

\begin{tabular}{lccccc}
\hline & Class & Education & Education $\neq$ & Status & Income \\
\hline \hline Class & $1.00^{* *}$ & & & & \\
Education ${ }^{*}$ & $0.57^{* *}$ & $1.00^{* *}$ & & & \\
Education & $0.59^{* *}$ & $0.96^{* *}$ & $1.00^{* *}$ & & \\
Status & $0.73^{* *}$ & $0.54^{* *}$ & $0.58^{* *}$ & $1.00^{* *}$ & \\
Income & $0.51^{* *}$ & $0.51^{* *}$ & $0.53^{* *}$ & $0.47^{* *}$ & $1.00^{* *}$ \\
\hline
\end{tabular}

Notes: Values have been reversed so that lower values indicate a lower status/class/education category

All variables have been normalised between $0-1$

† Uses 7-level relative scale

$\ddagger$ Uses Composite Measure

$* * \mathrm{p}<0.01$ 


\section{Social Origin and Cognitive Ability}

This section examines how cognitive ability, measured at age 10, is associated with each measure of social origin described above. Figure 11 and Table 41 consider how cognitive ability is distributed across social class categories.

Figure 11. Boxplot Distribution of Cognitive Ability by Parental Class

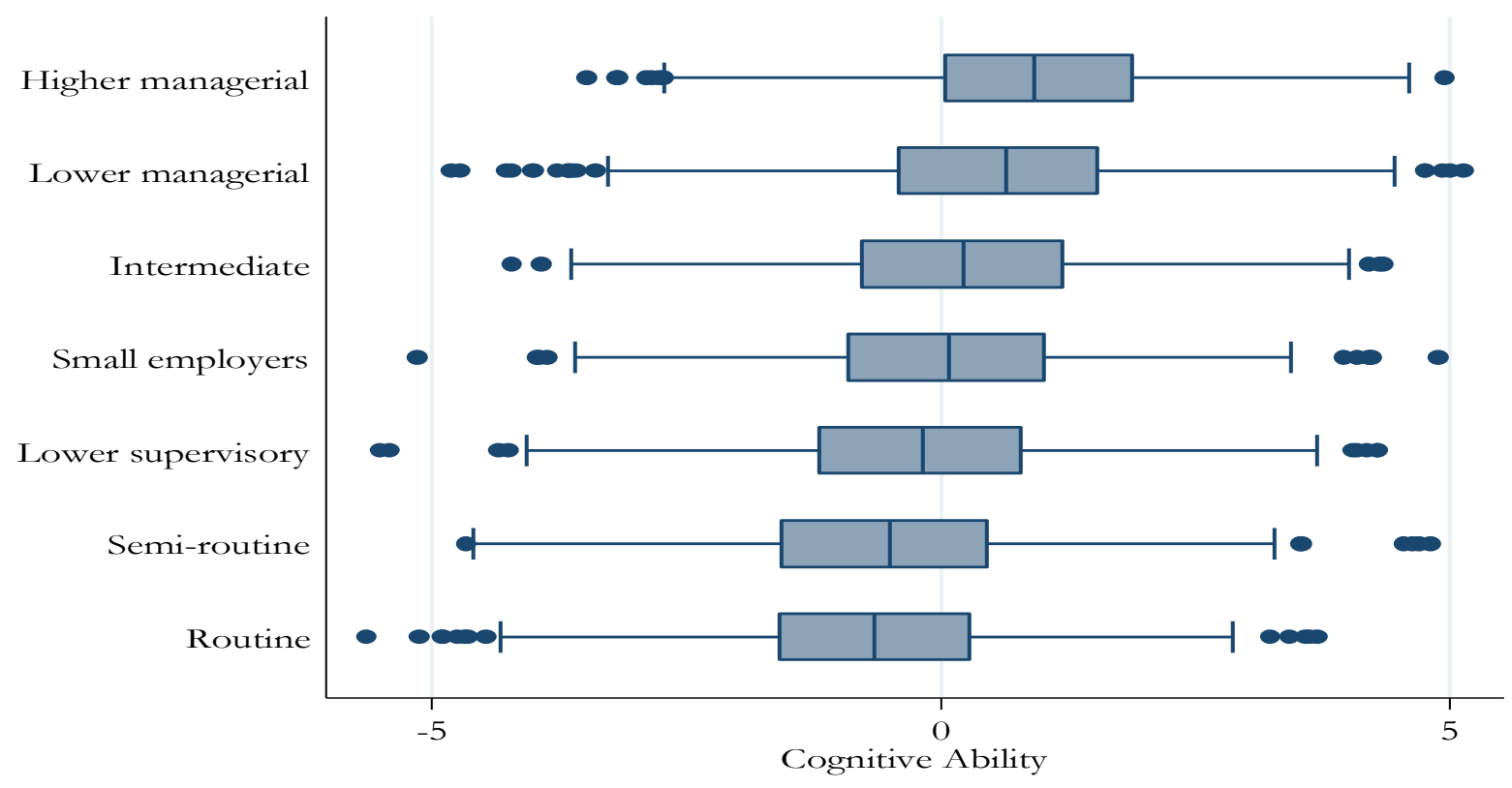

Table 41. Mean Cognitive Ability by Parental Class

\begin{tabular}{lccc}
\hline NS-SEC (reduced method) & Mean & Std. Dev. & Freq. \\
\hline \hline 1. Higher managerial & 0.92 & 1.37 & 1069 \\
2. Lower managerial & 0.56 & 1.42 & 2191 \\
3. Intermediate & 0.19 & 1.44 & 914 \\
4. Small employers & 0.05 & 1.39 & 1264 \\
5. Lower supervisory & -0.21 & 1.44 & 1889 \\
6. Semi routine & -0.52 & 1.47 & 1364 \\
7. Routine & -0.67 & 1.60 & 1266 \\
\hline
\end{tabular}

Table 42 and Figure 12 provide identical summaries by quintiles of parental CG status. Table 43 then provides a cross-tabulation of parental status quintiles by cognitive ability quintiles. The two measures, in their original interval forms, are correlated at $0.33(\mathrm{p}<0.01)$.

Table 42. Mean Cognitive Ability by Parental CG Status Quintiles

\begin{tabular}{lccc}
\hline Chan-Goldthorpe Status & Mean & Std. Dev. & Freq. \\
\hline \hline $1^{\text {st }}$ Quintile (Lowest) & -0.51 & 1.44 & 2457 \\
$2^{\text {nd }}$ Quintile & -0.35 & 1.43 & 1713 \\
$3^{\text {rd }}$ Quintile & -0.05 & 1.42 & 2094 \\
$4^{\text {th }}$ Quintile & 0.25 & 1.41 & 1946 \\
$5^{\text {th }}$ Quintile (Highest) & 0.96 & 1.37 & 1919 \\
\hline
\end{tabular}


Figure 12. Boxplot Distribution of Cognitive Ability by Parental CG Status Quintiles

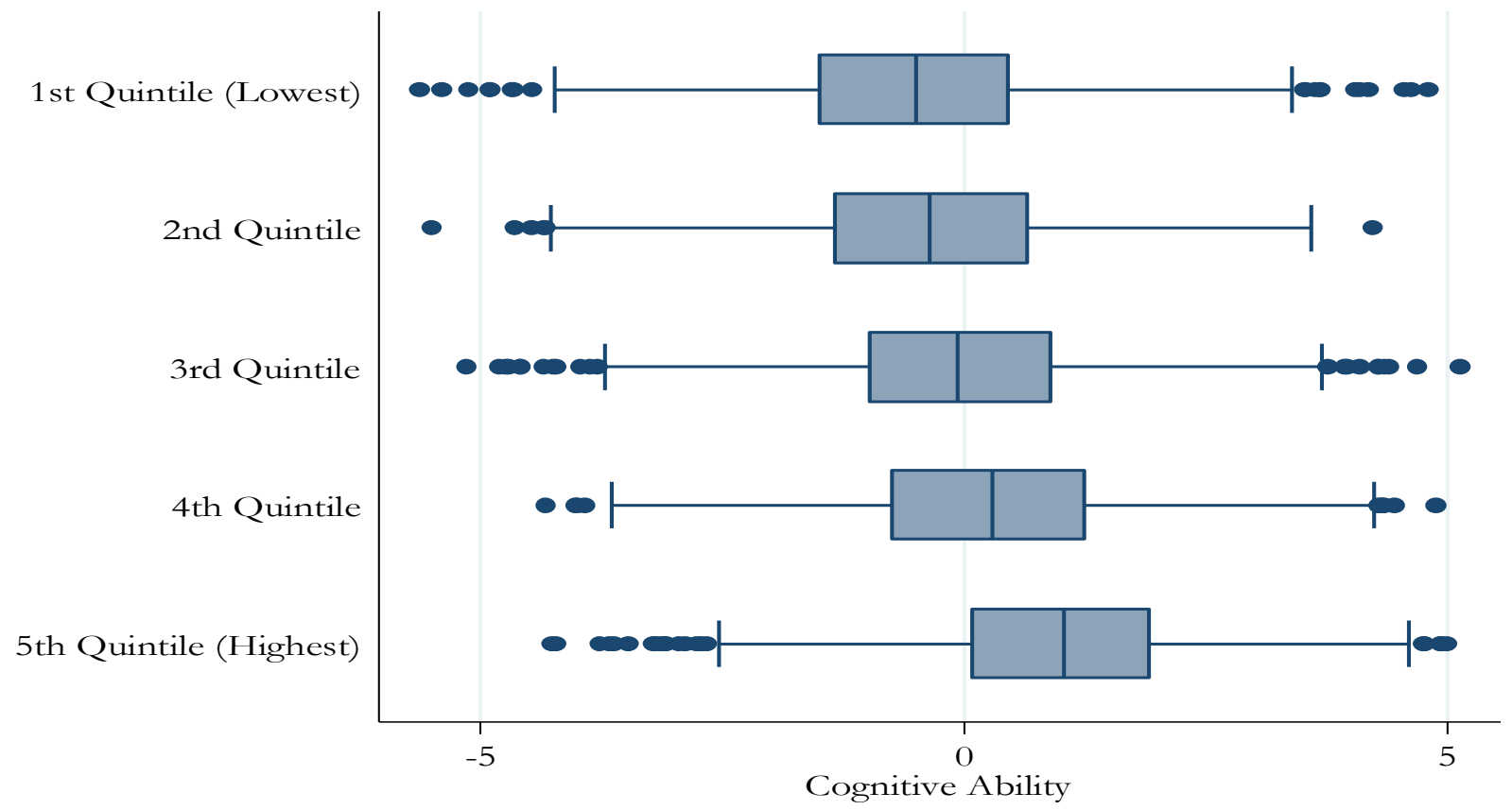

Table 43. Cross-Tabulation of Parental CG Status Quintiles by Cognitive Ability Quintiles

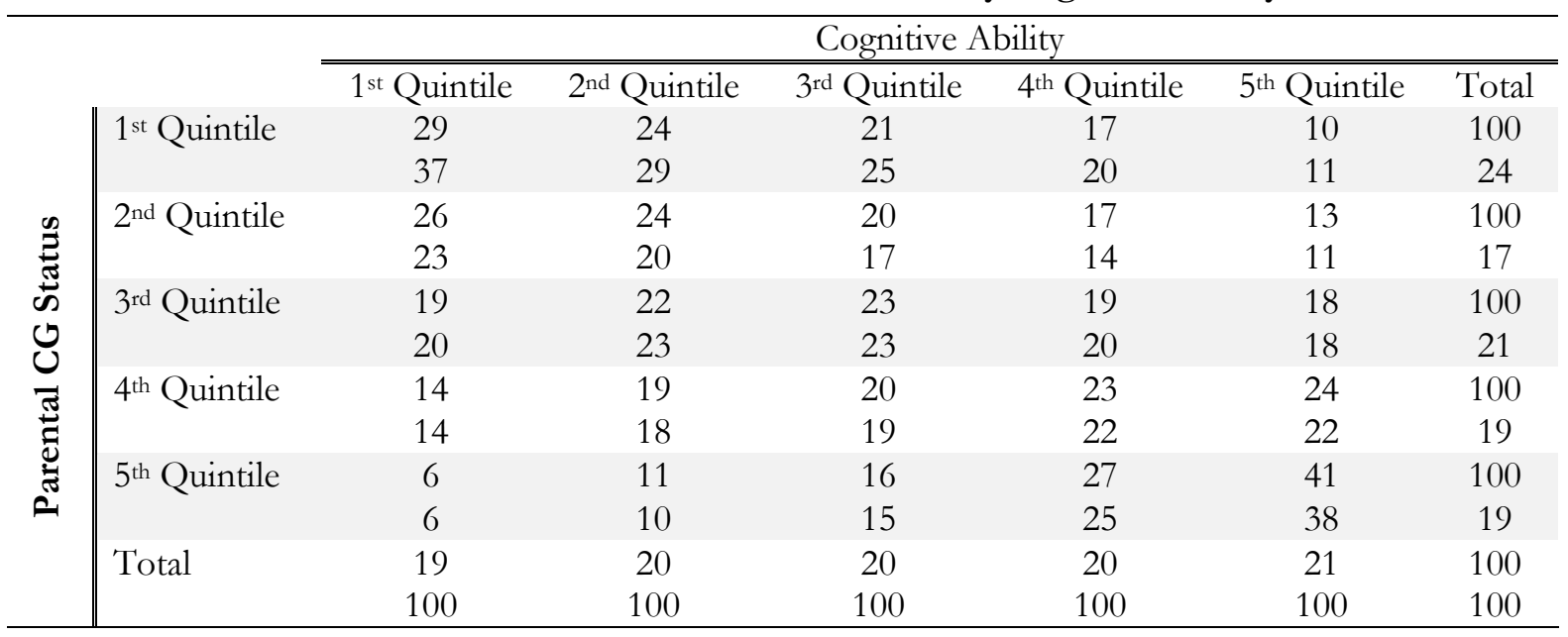

Table 46 uses the composite parental education measure to examine the distribution of cognitive ability scores across categories.

Table 44. Mean Cognitive Ability by Parental Education

\begin{tabular}{lccccc}
\hline & Mean & SD & Min & Max & N \\
\hline \hline 1. Neither parent has any qualification & -0.58 & 1.41 & -5.64 & 4.85 & 3466 \\
2. & -0.18 & 1.39 & -5.40 & 4.76 & 2046 \\
3. & 0.19 & 1.43 & -5.51 & 5.13 & 2066 \\
4. & 0.43 & 1.36 & -4.27 & 4.63 & 1226 \\
5. & 0.97 & 1.35 & -4.27 & 4.21 & 230 \\
6. & 1.07 & 1.31 & -4.21 & 4.99 & 1114 \\
7. Both parents have degrees & 1.65 & 1.23 & -2.94 & 4.60 & 209 \\
\hline
\end{tabular}


Cognitive ability is now examined in terms of the distribution of scores across income quintiles. See Table 45. The two measures, in their original interval forms, are correlated at $0.32(\mathrm{p}<0.01)$.

Table 45. Mean Cognitive Ability by Parental Income Quintiles

\begin{tabular}{lccc}
\hline Parental Income & Mean & Std. Dev. & Freq. \\
\hline \hline $1^{\text {st }}$ Quintile (Lowest) & -0.48 & 1.45 & 1148 \\
$2^{\text {nd }}$ Quintile & -0.09 & 1.49 & 884 \\
$3^{\text {rd }}$ Quintile & 0.16 & 1.43 & 1261 \\
$4^{\text {th }}$ Quintile & 0.43 & 1.44 & 825 \\
$5^{\text {th }}$ Quintile (Highest) & 0.90 & 1.39 & 996 \\
\hline
\end{tabular}

Finally, $5 \times 5$ contingency tables were produced for all social origin-by-cognitive ability quintile pairs. For social class, the variable was recoded to five ordinal categories (i.e. classes 3-5 were collapsed); for parental CG status, quintiles were used; for parental education, categories $2-3$ and categories 6-7 were collapsed); and for parental income, quintiles were used. These tables are not reproduced here, but each reinforces the general trend that those from more advantaged social backgrounds - however defined - tend to have higher scores of cognitive ability.

In an attempt to determine whether the association between cognitive ability and social origin differs according to how one choses to operationalise the latter, global log odds ratios were calculated for each of the tables, using the method proposed by Cox and Jackson (2009). Differences between the averages of the centre four global log odds ratios were calculated for each pair of tables, and were then tested for significance. The results of these tests are given in Table 46 below.

Table 46. Average Centre Four Global Log Odds Ratios and a Test of Significance in the Differences

\begin{tabular}{lcccccc}
\hline & \multicolumn{2}{c}{ Average Centre Four } & Difference & SE Difference & Lower CI & Upper CI \\
\cline { 2 - 3 } & i & ii & & & & \\
\cline { 2 - 3 } i.Class-ii.Status & 1.04 & 1.00 & 0.04 & 0.05 & -0.14 & 0.06 \\
i.Class-ii.Education & 1.04 & 1.48 & $0.44^{* *}$ & 0.06 & 0.31 & 0.56 \\
i.Class-ii.Income & 1.04 & 0.96 & 0.09 & 0.07 & -0.21 & 0.04 \\
i.Status-ii.Education & 1.00 & 1.48 & $0.48^{* *}$ & 0.06 & 0.35 & 0.60 \\
i.Status-ii.Income & 1.00 & 0.96 & 0.04 & 0.06 & -0.17 & 0.08 \\
i.Education-ii.Income & 1.48 & 0.96 & $0.52^{* *}$ & 0.07 & -0.67 & 0.39 \\
\hline
\end{tabular}

The overall association, measured via global log odds, between cognitive ability and parental education is significantly different to the overall association between cognitive ability and any of the other social origin measures. No other differences between associations are statistically significant. 


\section{Social Origin and Educational Attainment}

This section examines the relationship between each of the social origin measures and the main outcome variable of respondents' educational attainment at age 38. Tables 47-50 present cross-tabulations between parental class, education, status and income by respondents' educational attainment.

Table 47. Cross-Tabulation of Parental Class by Cohort Members' Educational Attainment at age 38

\begin{tabular}{|c|c|c|c|c|c|c|c|c|c|}
\hline \multirow[b]{2}{*}{$\begin{array}{l}\text { Parental } \\
\text { NS-SEC }\end{array}$} & \multicolumn{7}{|c|}{ Cohort Member's Educational Attainment at Age 38} & \multirow[b]{2}{*}{ Total } & \\
\hline & 1 & 2 & 3 & 4 & 5 & 6 & 7 & & \\
\hline \multirow{3}{*}{ Higher managerial } & 64 & 33 & 121 & 190 & 54 & 187 & 507 & 1156 & $\mathrm{~N}$ \\
\hline & 6 & 3 & 10 & 16 & 5 & 16 & 44 & 100 & Row $\%$ \\
\hline & 5 & 4 & 6 & 9 & 20 & 13 & 25 & 11 & Column \% \\
\hline \multirow{3}{*}{ Lower managerial } & 207 & 106 & 383 & 489 & 78 & 371 & 658 & 2292 & $\mathrm{~N}$ \\
\hline & 9 & 5 & 17 & 21 & 3 & 16 & 29 & 100 & Row \% \\
\hline & 16 & 14 & 18 & 23 & 29 & 25 & 33 & 23 & Column \% \\
\hline \multirow{3}{*}{ Intermediate } & 90 & 58 & 185 & 218 & 25 & 147 & 173 & 896 & $\mathrm{~N}$ \\
\hline & 10 & 6 & 21 & 24 & 3 & 16 & 19 & 100 & Row \% \\
\hline & 7 & 8 & 9 & 10 & 9 & 10 & 9 & 9 & Column \% \\
\hline \multirow{3}{*}{ Small employers } & 188 & 115 & 260 & 289 & 37 & 200 & 221 & 1310 & $\mathrm{~N}$ \\
\hline & 14 & 9 & 20 & 22 & 3 & 15 & 17 & 100 & Row \% \\
\hline & 14 & 15 & 12 & 13 & 14 & 14 & 11 & 13 & Column \% \\
\hline \multirow{3}{*}{ Lower supervisory } & 257 & 174 & 465 & 430 & 37 & 272 & 209 & 1844 & $\mathrm{~N}$ \\
\hline & 14 & 9 & 25 & 23 & 2 & 15 & 11 & 100 & Row \% \\
\hline & 19 & 23 & 22 & 20 & 14 & 18 & 10 & 18 & Column \% \\
\hline \multirow{3}{*}{ Semi routine } & 225 & 150 & 341 & 261 & 21 & 168 & 123 & 1289 & $\mathrm{~N}$ \\
\hline & 17 & 12 & 26 & 20 & 2 & 13 & 10 & 100 & Row \% \\
\hline & 17 & 20 & 16 & 12 & 8 & 11 & 6 & 13 & Column \% \\
\hline \multirow{3}{*}{ Routine } & 299 & 116 & 379 & 269 & 19 & 129 & 102 & 1313 & $\mathrm{~N}$ \\
\hline & 23 & 9 & 29 & 20 & 1 & 10 & 8 & 100 & Row \% \\
\hline & 22 & 15 & 18 & 13 & 7 & 9 & 5 & 13 & Column \% \\
\hline \multirow{3}{*}{ Total } & 1330 & 752 & 2134 & 2146 & 271 & 1474 & 1993 & 10100 & $\mathrm{~N}$ \\
\hline & 13 & 7 & 21 & 21 & 3 & 15 & 20 & 100 & Row \% \\
\hline & 100 & 100 & 100 & 100 & 100 & 100 & 100 & 100 & Column \% \\
\hline
\end{tabular}

Note: Cohort members educational attainment categories are as follows:

1. No qualifications

2. Below O-level, NVQ 1 [Sub-secondary]

3. 1-4 O-level passes, NVQ2 [Secondary-low performance]

4. 5+ O-level passes or 1 A-level pass, NVQ 3 [Secondary-high perf.]

5. 2+ A-level passes [Higher secondary]

6. Tertiary sub-degree qualification, NVQ 4 [Lower tertiary]

7. Degree, NVQ 5 or 6 , higher degree [Higher tertiary] 
Table 48. Cross-Tabulation of Parental Education (Combined Approach 2) by Cohort Members' Educational Attainment at age 38

\begin{tabular}{|c|c|c|c|c|c|c|c|c|c|}
\hline \multirow[b]{2}{*}{$\begin{array}{l}\text { Parental } \\
\text { Education }\end{array}$} & \multicolumn{7}{|c|}{ Cohort Member's Educational Attainment at Age 38} & \multirow[b]{2}{*}{ Total } & \\
\hline & 1 & 2 & 3 & 4 & 5 & 6 & 7 & & \\
\hline \multirow{3}{*}{ 1. No qualifications } & 655 & 371 & 827 & 646 & 50 & 407 & 255 & 3211 & $\mathrm{~N}$ \\
\hline & 20 & 12 & 26 & 20 & 2 & 13 & 8 & 100 & Row \% \\
\hline & 47 & 48 & 38 & 30 & 18 & 27 & 13 & 31 & Column \% \\
\hline \multirow{3}{*}{2} & 314 & 165 & 520 & 474 & 44 & 276 & 249 & 2042 & $\mathrm{~N}$ \\
\hline & 15 & 8 & 25 & 23 & 2 & 14 & 12 & 100 & Row \% \\
\hline & 22 & 21 & 24 & 22 & 16 & 18 & 12 & 20 & Column \% \\
\hline \multirow{3}{*}{3} & 215 & 148 & 470 & 497 & 66 & 343 & 370 & 2109 & $\mathrm{~N}$ \\
\hline & 10 & 7 & 22 & 24 & 3 & 16 & 18 & 100 & Row \% \\
\hline & 15 & 19 & 22 & 23 & 24 & 23 & 18 & 20 & Column $\%$ \\
\hline \multirow{3}{*}{4} & 117 & 53 & 216 & 304 & 45 & 213 & 314 & 1262 & $\mathrm{~N}$ \\
\hline & 9 & 4 & 17 & 24 & 4 & 17 & 25 & 100 & Row \% \\
\hline & 8 & 7 & 10 & 14 & 17 & 14 & 16 & 12 & Column \% \\
\hline \multirow{3}{*}{5} & 19 & 6 & 28 & 44 & 11 & 38 & 105 & 251 & $\mathrm{~N}$ \\
\hline & 8 & 2 & 11 & 18 & 4 & 15 & 42 & 100 & Row \% \\
\hline & 1 & 1 & 1 & 2 & 4 & 3 & 5 & 2 & Column \% \\
\hline \multirow{3}{*}{6} & 63 & 28 & 104 & 187 & 50 & 204 & 569 & 1205 & $\mathrm{~N}$ \\
\hline & 5 & 2 & 9 & 16 & 4 & 17 & 47 & 100 & Row \% \\
\hline & 5 & 4 & 5 & 9 & 18 & 14 & 28 & 12 & Column $\%$ \\
\hline \multirow{3}{*}{ 7. Both have degrees } & 16 & 5 & 9 & 23 & 6 & 21 & 160 & 240 & $\mathrm{~N}$ \\
\hline & 7 & 2 & 4 & 10 & 3 & 9 & 67 & 100 & Row $\%$ \\
\hline & 1 & 1 & 0 & 1 & 2 & 1 & 8 & 2 & Column \% \\
\hline \multirow{3}{*}{ Total } & 1399 & 776 & 2174 & 2175 & 272 & 1502 & 2022 & 10320 & $\mathrm{~N}$ \\
\hline & 14 & 8 & 21 & 21 & 3 & 15 & 20 & 100 & Row \% \\
\hline & 100 & 100 & 100 & 100 & 100 & 100 & 100 & 100 & Column $\%$ \\
\hline
\end{tabular}


Table 49. Cross-Tab. of Parental CG Status Quartiles by Cohort Members' Educ. Attainment at age 38

\begin{tabular}{|c|c|c|c|c|c|c|c|c|c|}
\hline \multirow[b]{2}{*}{$\begin{array}{l}\text { Parental } \\
\text { CG Status }\end{array}$} & \multicolumn{7}{|c|}{ Cohort Member's Educational Attainment at Age 38} & \multirow[b]{2}{*}{ Total } & \\
\hline & 1 & 2 & 3 & 4 & 5 & 6 & 7 & & \\
\hline \multirow{3}{*}{$1^{\text {st }}$ Quartile } & 513 & 251 & 698 & 566 & 55 & 346 & 293 & 2722 & $\mathrm{~N}$ \\
\hline & 19 & 9 & 26 & 21 & 2 & 13 & 11 & 100 & Row $\%$ \\
\hline & 39 & 33 & 33 & 26 & 20 & 23 & 15 & 27 & Column $\%$ \\
\hline \multirow{3}{*}{$2^{\text {nd }}$ Quartile } & 405 & 260 & 676 & 636 & 61 & 374 & 373 & 2785 & $\mathrm{~N}$ \\
\hline & 15 & 9 & 24 & 23 & 2 & 13 & 13 & 100 & Row \% \\
\hline & 30 & 35 & 32 & 30 & 23 & 25 & 19 & 28 & Column $\%$ \\
\hline \multirow{3}{*}{$3^{\text {rd }}$ Quartile } & 241 & 157 & 442 & 508 & 65 & 350 & 379 & 2142 & $\mathrm{~N}$ \\
\hline & 11 & 7 & 21 & 24 & 3 & 16 & 18 & 100 & Row \% \\
\hline & 18 & 21 & 21 & 24 & 24 & 24 & 19 & 21 & Column $\%$ \\
\hline \multirow{3}{*}{$4^{\text {th }}$ Quartile } & 171 & 84 & 318 & 436 & 90 & 404 & 948 & 2451 & $\mathrm{~N}$ \\
\hline & 7 & 3 & 13 & 18 & 4 & 16 & 39 & 100 & Row \% \\
\hline & 13 & 11 & 15 & 20 & 33 & 27 & 48 & 24 & Column $\%$ \\
\hline \multirow{3}{*}{ Total } & 1330 & 752 & 2134 & 2146 & 271 & 1474 & 1993 & 10100 & $\mathrm{~N}$ \\
\hline & 13 & 7 & 21 & 21 & 3 & 15 & 20 & 100 & Row \% \\
\hline & 100 & 100 & 100 & 100 & 100 & 100 & 100 & 100 & Column $\%$ \\
\hline
\end{tabular}

Note: Cohort members educational attainment categories are as follows:

1. No qualifications

2. Below O-level, NVQ 1 [Sub-secondary]

3. 1-4 O-level passes, NVQ2 [Secondary-low performance]

4. 5+ O-level passes or 1 A-level pass, NVQ 3 [Secondary-high perf.]

5. 2+ A-level passes [Higher secondary]

6. Tertiary sub-degree qualification, NVQ 4 [Lower tertiary]

7. Degree, NVQ 5 or 6 , higher degree [Higher tertiary] 
Table 50. Cross-Tab. of Parental Income Quartiles by Cohort Members' Educ. Attainment at Age 38

\begin{tabular}{|c|c|c|c|c|c|c|c|c|c|}
\hline \multirow{2}{*}{$\begin{array}{l}\text { Parental } \\
\text { CG Status } \\
\end{array}$} & \multicolumn{7}{|c|}{ Cohort Member's Educational Attainment at Age 38} & \multirow{2}{*}{\multicolumn{2}{|c|}{ Total }} \\
\hline & 1 & 2 & 3 & 4 & 5 & 6 & 7 & & \\
\hline \multirow{3}{*}{$1^{\text {st }}$ Quartile } & 274 & 119 & 389 & 314 & 16 & 203 & 169 & 1484 & $\mathrm{~N}$ \\
\hline & 18 & 8 & 26 & 21 & 1 & 14 & 11 & 100 & Row \% \\
\hline & 41 & 33 & 35 & 27 & 11 & 25 & 15 & 28 & Column $\%$ \\
\hline \multirow{3}{*}{$2^{\text {nd }}$ Quartile } & 177 & 117 & 299 & 298 & 23 & 182 & 180 & 1276 & $\mathrm{~N}$ \\
\hline & 14 & 9 & 23 & 23 & 2 & 14 & 14 & 100 & Row \% \\
\hline & 27 & 32 & 27 & 26 & 16 & 22 & 16 & 24 & Column $\%$ \\
\hline \multirow{3}{*}{ 3rd Quartile } & 121 & 73 & 245 & 298 & 49 & 212 & 285 & 1283 & $\mathrm{~N}$ \\
\hline & 9 & 6 & 19 & 23 & 4 & 17 & 22 & 100 & Row \% \\
\hline & 18 & 20 & 22 & 26 & 34 & 26 & 25 & 24 & Column \% \\
\hline \multirow{3}{*}{$4^{\text {th }}$ Quartile } & 93 & 56 & 178 & 237 & 57 & 219 & 505 & 1345 & $\mathrm{~N}$ \\
\hline & 7 & 4 & 13 & 18 & 4 & 16 & 38 & 100 & Row \% \\
\hline & 14 & 15 & 16 & 21 & 39 & 27 & 44 & 25 & Column $\%$ \\
\hline \multirow{3}{*}{ Total } & 665 & 365 & 1111 & 1147 & 145 & 816 & 1139 & 5388 & $\mathrm{~N}$ \\
\hline & 12 & 7 & 21 & 21 & 3 & 15 & 21 & 100 & Row \% \\
\hline & 100 & 100 & 100 & 100 & 100 & 100 & 100 & 100 & Column $\%$ \\
\hline
\end{tabular}

Note: Cohort members educational attainment categories are as follows:

1. No qualifications

2. Below O-level, NVQ 1 [Sub-secondary]

3. 1-4 O-level passes, NVQ2 [Secondary-low performance]

4. 5+ O-level passes or 1 A-level pass, NVQ 3 [Secondary-high perf.]

5. 2+ A-level passes [Higher secondary]

6. Tertiary sub-degree qualification, NVQ 4 [Lower tertiary]

7. Degree, NVQ 5 or 6 , higher degree [Higher tertiary] 


\section{Cognitive Ability and Educational Attainment}

This section will examine the association between early-life cognitive ability, measured at age 10, and educational attainment later in life. Mean cognitive ability scores are presented across categories of highest qualification achieved at the ages of 20 and $38 .{ }^{9}$ Table 51 shows that mean cognitive ability scores tend to rise with increased attainment, with the notable exception of those whose highest qualification at age 38 is equivalent to a tertiary sub-degree qualification; for these individuals, early-life cognitive ability is, on average, less than it is for those who achieved $2+$ A-level passes. The same was found for the NCDS cohort. Moreover, for individuals who are coded as having no qualification at age 20 , the mean cognitive ability score is somewhat higher than that for people in category two, and compared to individuals who are coded as having no qualification at age 38 .

Table 51. Mean Cognitive Ability by Educational Attainment at Ages 20 and 38

\begin{tabular}{|c|c|c|c|c|c|c|}
\hline & \multicolumn{3}{|c|}{ Age 20} & \multicolumn{3}{|c|}{ Age 38} \\
\hline & Mean & $\begin{array}{l}\text { Std. } \\
\text { Dev. }\end{array}$ & $\mathrm{N}$ & $\begin{array}{c}\text { Mean } \\
(\mathrm{SD})\end{array}$ & $\begin{array}{l}\text { Std. } \\
\text { Dev. }\end{array}$ & $\mathrm{N}$ \\
\hline 1. No qualifications & -0.49 & 1.50 & 2,050 & -0.74 & 1.47 & 1,183 \\
\hline 2. Below O-level, NVQ 1 & -0.66 & 1.27 & 716 & -0.62 & 1.33 & 659 \\
\hline 3. 1-4 O-level passes, NVQ 2 & -0.28 & 1.27 & 1,973 & -0.41 & 1.29 & 1,874 \\
\hline $\begin{array}{l}\text { 4. } 5+\text { O-level passes or } 1 \text { A-level pass, NVQ } \\
3\end{array}$ & 0.45 & 1.32 & 2,301 & 0.14 & 1.32 & 1,899 \\
\hline 5. $2+$ A-level passes & 1.46 & 1.21 & 1,206 & 1.00 & 1.21 & 235 \\
\hline 6. Tertiary sub-degree qualification, NVQ 4 & 0.33 & 1.31 & 559 & 0.31 & 1.35 & 1,277 \\
\hline 7. Degree, NVQ 5 or 6 , higher degree & - & - & 3 & 1.25 & 1.26 & 1,681 \\
\hline Total & 0.11 & 1.49 & 8,808 & 0.11 & 1.49 & 8,808 \\
\hline
\end{tabular}

Following Bukodi and Goldthorpe (2013), Table 52 takes an alternative approach using the same information; mean scores are examined according to whether individuals passed various qualification thresholds. The first threshold compares those who attained some level of qualification (categories $2-7$ in Table 51 above) rather than none (category 1), the second threshold compares those who attained qualifications at NVQ 1 or higher (categories 3-7) with those whose attainment is lower (categories 1-2), and so on.

\footnotetext{
${ }^{9}$ Educational attainment up until age 20 is also considered because this is the latest age for which we have attainment information for the LSYPE sample.
} 
Table 52. Mean Cognitive Ability by Educational Attainment Thresholds at Ages 20 and 38

\begin{tabular}{|c|c|c|c|c|}
\hline \multicolumn{5}{|c|}{ Age 20} \\
\hline & Mean (SD) & $\mathrm{N}$ & Mean (SD) & $\mathrm{N}$ \\
\hline \multicolumn{5}{|c|}{ Threshold i. } \\
\hline 1 & $-0.49(1.50)$ & 2050 & $-0.74(1.47)$ & 1183 \\
\hline $2-7$ & $0.29(1.44)$ & 6758 & $0.24(1.45)$ & 7625 \\
\hline \multicolumn{5}{|c|}{ Threshold ii. } \\
\hline $1-2$ & $-0.54(1.44)$ & 2766 & $-0.70(1.42)$ & 1842 \\
\hline $3-7$ & $0.40(1.42)$ & 6042 & $0.32(1.44)$ & 6966 \\
\hline \multicolumn{5}{|c|}{ Threshold iii. } \\
\hline $1-3$ & $-0.43(1.38)$ & 4739 & $-0.55(1.36)$ & 3716 \\
\hline $4-7$ & $0.73(1.37)$ & 4069 & $0.59(1.40)$ & 5092 \\
\hline \multicolumn{5}{|c|}{ Threshold iv. } \\
\hline $1-4$ & $-0.14(1.42)$ & 7040 & $-0.32(1.39)$ & 5615 \\
\hline $5-7$ & $1.10(1.35)$ & 1768 & $0.86(1.37)$ & 3193 \\
\hline \multicolumn{5}{|c|}{ Threshold v. } \\
\hline $1-5$ & $0.92(1.50)$ & 8,246 & $-0.27(1.41)$ & 5850 \\
\hline $6-7$ & $0.33(1.31)$ & 562 & $0.84(1.38)$ & 2958 \\
\hline \multicolumn{5}{|c|}{ Threshold vi. } \\
\hline $1-6$ & - & - & $-0.16(1.41)$ & 7127 \\
\hline 7 & - & - & $1.25(1.27)$ & 1681 \\
\hline
\end{tabular}

Table 53 reports the means of cognitive ability by the type of threshold.

Table 53. Mean Cognitive Ability Scores by Type of Educational Threshold (Age 38)

\begin{tabular}{|c|c|c|c|c|c|c|}
\hline & \multicolumn{6}{|c|}{ KS5 Transition } \\
\hline & \multicolumn{3}{|c|}{ Academic only } & \multicolumn{3}{|c|}{ Academic and vocational } \\
\hline & Mean & Std. Dev. & $\mathrm{N}$ & Mean & Std. Dev. & $\mathrm{N}$ \\
\hline No & -0.28 & 1.39 & 6,114 & -0.32 & 1.39 & 5,615 \\
\hline Yes & 0.98 & 1.35 & 2,694 & 0.86 & 1.37 & 3,193 \\
\hline
\end{tabular}

HE Transition

\begin{tabular}{|c|c|c|c|c|c|c|}
\hline & \multicolumn{3}{|c|}{ Academic only } & \multicolumn{3}{|c|}{ Academic and vocational } \\
\hline & Mean & Std. Dev. & $\mathrm{N}$ & Mean & Std. Dev. & $\mathrm{N}$ \\
\hline No & -0.16 & $1 . \overline{4}$ & 7,170 & $-\overline{0.16}$ & $1 . \overline{4} 1$ & 7,127 \\
\hline Yes & 1.26 & 1.26 & 1,638 & 1.25 & 1.26 & 1,681 \\
\hline
\end{tabular}




\section{Appendix}

Table 54. Details on coding of variables on fathers' and mothers' educational attainment

\begin{tabular}{ll}
\hline Categories of Original Variable & Categories of generated variable \\
\hline \hline Out of range & \\
$\begin{array}{l}\text { Not stated } \\
\text { Other qualification } \\
\text { Other qual specify }\end{array}$ & Missing \\
\hline O level or equiv & O-level / Trade apprentice \\
Trade apprenticeship & A-level \\
\hline A level or equiv & Sub-degree qualification \\
\hline SRN & Degree \\
Cert of education & No qualification \\
\hline Degree & \\
\hline
\end{tabular}

Table 55. Cross-tabulation between Parental Social Class and Parental Education (Composite measure)

\begin{tabular}{lcccccccc}
\hline & $\begin{array}{c}\text { 1. No } \\
\text { qualific } \\
\text { ations }\end{array}$ & $\mathbf{2}$ & $\mathbf{3}$ & $\mathbf{4}$ & $\mathbf{5}$ & $\mathbf{6}$ & $\begin{array}{c}\text { 7. Both } \\
\text { have } \\
\text { degree } \\
\text { s }\end{array}$ & Total \\
\hline \hline Higher & 69 & 86 & 135 & 198 & 47 & 725 & 165 & 1,425 \\
managerial & 4.84 & 6.04 & 9.47 & 13.89 & 3.3 & 50.88 & 11.58 & 100 \\
Lower & 1.64 & 3.37 & 5.27 & 12.66 & 15.16 & 49.52 & 57.89 & 11.02 \\
managerial & 389 & 399 & 584 & 625 & 194 & 531 & 101 & 2,823 \\
& 13.78 & 14.13 & 20.69 & 22.14 & 6.87 & 18.81 & 3.58 & 100 \\
Intermediate & 9.27 & 15.64 & 22.8 & 39.96 & 62.58 & 36.27 & 35.44 & 21.83 \\
& 262 & 262 & 390 & 149 & 16 & 70 & 7 & 1,156 \\
Small employers & 22.66 & 22.66 & 33.74 & 12.89 & 1.38 & 6.06 & 0.61 & 100 \\
& 6.24 & 10.27 & 15.23 & 9.53 & 5.16 & 4.78 & 2.46 & 8.94 \\
Lower & 489 & 415 & 422 & 213 & 29 & 77 & 9 & 1,654 \\
supervisory & 29.56 & 25.09 & 25.51 & 12.88 & 1.75 & 4.66 & 0.54 & 100 \\
& 11.65 & 16.27 & 16.48 & 13.62 & 9.35 & 5.26 & 3.16 & 12.79 \\
Semi routine & 761 & 689 & 566 & 247 & 13 & 42 & 2 & 2,320 \\
& 32.8 & 29.7 & 24.4 & 10.65 & 0.56 & 1.81 & 0.09 & 100 \\
& 18.14 & 27.01 & 22.1 & 15.79 & 4.19 & 2.87 & 0.7 & 17.94 \\
Routine & 996 & 369 & 258 & 76 & 6 & 8 & 1 & 1,714 \\
& 58.11 & 21.53 & 15.05 & 4.43 & 0.35 & 0.47 & 0.06 & 100 \\
& 23.74 & 14.46 & 10.07 & 4.86 & 1.94 & 0.55 & 0.35 & 13.25 \\
Total & 1,230 & 331 & 206 & 56 & 5 & 11 & 0 & 1,839 \\
& 66.88 & 18 & 11.2 & 3.05 & 0.27 & 0.6 & 0 & 100 \\
& 29.31 & 12.98 & 8.04 & 3.58 & 1.61 & 0.75 & 0 & 14.22 \\
& 4,196 & 2,551 & 2,561 & 1,564 & 310 & 1,464 & 285 & 12,931 \\
& 32.45 & 19.73 & 19.81 & 12.09 & 2.4 & 11.32 & 2.2 & 100 \\
& 100 & 100 & 100 & 100 & 100 & 100 & 100 & 100 \\
\hline
\end{tabular}

Note: First row $=$ Frequencies; Second row $=$ Row percentages; Third row $=$ Column percentages 